Bruno Vinícius Pimenta de Almada

\title{
Comparação entre fontes de células- tronco mesenquimais na indução à regeneração óssea
}

Comparison of mesenchymal stem cells from different sources in inducing bone

formation 


\section{Bruno Vinícius Pimenta de Almada}

Comparação entre fontes de células-tronco mesenquimais na indução à regeneração óssea

Comparison of mesenchymal stem cells from different sources in inducing bone formation

Dissertação apresentada ao Instituto de Biociências da Universidade de São Paulo, para a obtenção de Título de Mestre em Ciências, na Área de Biologia/Genética.

Orientadora: Maria Rita dos Santos e Passos-Bueno 


\section{Ficha Catalográfica}

Bruno Vinícius Pimenta de Almada

Comparação entre fontes de célulastronco mesenquimais na indução à regeneração óssea. 80 páginas

Dissertação (Mestrado) - Instituto de Biociências da Universidade de São Paulo. Departamento de Genética e Biologia Evolutiva.

1. Engenharia de tecidos 2. Células-tronco de dentes decíduos esfoliados 3. Células-tronco de músculo orbicular do lábio. Universidade de São Paulo. Instituto de Biociências. Departamento Genética e Biologia Evolutiva.

\section{Comissão Julgadora:}

\section{Prof(a). Dr.(a). \\ Orientador(a)}


Dedico esta dissertação aos meus pais João e Marcia; por todo o apoio incondicional em todos os momentos de minha vida.

Dedico a minha noiva Joyce por todo o amor e carinho. 
De tudo ficaram três coisas:

A certeza de que estamos começando,

A certeza de que é preciso continuar e

A certeza de que podemos ser interrompidos antes de terminar

Fazer da interrupção um caminho novo,

Fazer da queda um passo de dança,

Do medo uma escola,

Do sonho uma ponte,

Da procura um encontro,

E assim terá valido a pena existir!

SABINO, Fernando. Encontro Marcado 


\section{Agradecimentos}

Este trabalho é fruto da contribuição de muitos, assim como na vida, nada é construído sozinho. Várias pessoas foram importantes para que este objetivo fosse alcançado, assim, a escrita dos agradecimentos é uma parte difícil da dissertação, pois corro o risco de cometer alguma injustiça ao deixar mencionar nomes de pessoas que também contribuíram para o trabalho.

Agradeço a minha orientadora Drạ Maria Rita Passos Bueno, não só por ser uma ótima orientadora mas também pelas oportunidades a mim concedidas e por acreditar que poderia dar certo. Sempre Ihe serei grato.

À Drạ Luciane Portas Capelo, uma excelente amiga, que juntamente com a Rita me orientou na execução deste trabalho. Obrigado pelos conselhos, pelas conversas, os desabafos, paciência e pela grande contribuição neste trabalho.

À Dra Marilia Trierveiler Martins, professora da Faculdade de Odontologia da USP. Obrigado pela colaboração, ensinamentos, disponibilidade e por deixar o seu laboratório sempre de portas abertas para mim.

À Drạ Cecília Helena de A. Gouveia Ferreira, professora do Instituto de Ciências Biomédicas da USP. Obrigado pela colaboração e disponibilização do equipamento de micro-CT.

À Dra Daniela Franco Bueno, que me iniciou no estudo da bioengenharia de tecidos ósseos. Obrigado pela amizade, pelo companheirismo e também pelos momentos de diversão.

Ao Gerson, um grande amigo e quase um irmão. Obrigado pela ajuda nos experimentos de cultivo celular em plenos finais de semana ou durante a noite. E principalmente por todos os momentos fora do lab, com certeza você foi o responsável por deixar minha vida aqui em São Paulo mais agradável. 
Aos não somente colegas, mas também bons amigos do laboratório: Cintia, Simone, Melina, Daniele Moreira, Vanessa, Joana, Larissa, Carol, Felipe e Camila. Obrigado pela troca de experiências, pelos bons relacionamentos e por propiciar no laboratório um excelente ambiente para trabalhar. Além destes, gostaria de agradecer especialmente aos amigos: Rodrigo, Roberto, Luciano, May, Meire, Andressa, Karina, Ana Luiza, Lucas e Erika com os quais tive o prazer de compartilhar excelentes momentos dentro e fora do laboratório. Os churrascos na laje, as festas na USP e as cervejinhas foram essenciais para a concretização deste trabalho.

Aos novos amigos paulistas: He-man, Camila, Ligia, Maneco, Andrews, Lucas, Carolina Soares, Cintia Takeyama e até a Elaine. Além de todos meus companheiros e companheiras de república que conviveram comigo. Obrigado pelos momentos de descontração.

À toda a equipe do Centro de Estudo do Genoma Humano, em especial à Heloisa, Fernando, Vanessa Sato e Wagner.

À minha noiva Joyce, pelo carinho, respeito e por nunca ter desacreditado em nosso amor mesmo à distância. Obrigado por todo o passado e futuro que iremos compartilhar.

Aos meus pais, pelo amor, pelo apoio e pela dedicação incondicionais. Vocês foram imprescindíveis na conquista desta vitória.

Ao meu irmão, Hudson, pela amizade e companheirismo;

Este trabalho contou com o apoio financeiro do Conselho Nacional de Desenvolvimento Científico e Tecnológico (CNPq), da Fundação de Amparo à Pesquisa do Estado de São Paulo (FAPESP) e do Ministério da Ciência, Tecnologia e Inovação do Brasil. 
Esta dissertação de Mestrado compreende um trabalho inédito desenvolvido durante os anos de 2011 a 2013 no Laboratório de Genética do Desenvolvimento do Centro de Estudos do Genoma Humano do Instituto de Biociências da Universidade de São Paulo (CEGH/IB-USP).

Embora seja indicado no modelo tradicional de dissertação, pelo programa de pós-graduação do Instituto de Biociências, que se deva evitar o uso de anglicismos, alguns, como in vitro e in vivo, foram utilizados. Tais palavras não foram traduzidas para o português, pois são usadas corriqueiramente no meio científico e tem seu significado conhecido por esta comunidade. 


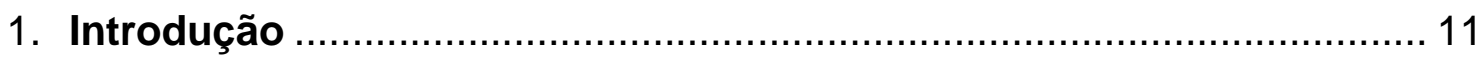

1.1. Sistema Esquelético e Regeneração ................................................ 11

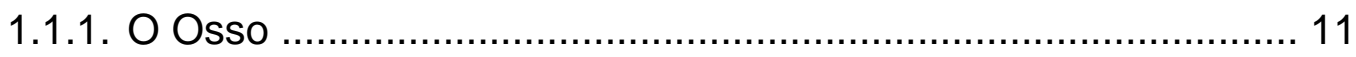

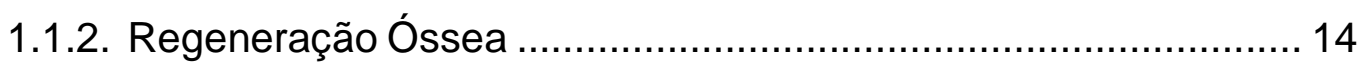

1.1.2.1. Enxertos Ósseos ......................................................... 15

1.2. Bioengenharia do Tecido Ósseo .................................................... 17

1.2.1. Noções Básicas da Biologia das Células-Tronco ......................... 18

1.2.1.1. Células-Tronco Mesenquimais ...................................... 21

1.2.1.1.1. Células-Tronco de Dentes Decíduos Esfoliados .... 22

1.2.1.1.2. Células-Tronco Derivadas de Músculo ................... 25

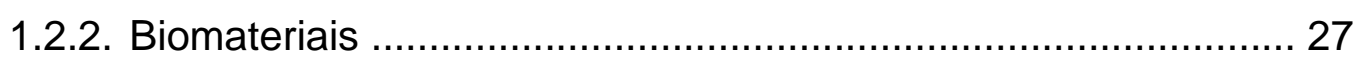

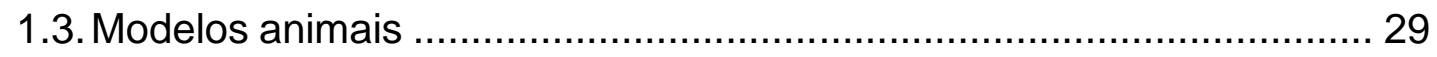

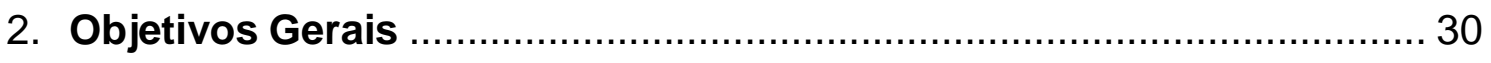

2.1. Objetivos Específicos ………..................................................... 30

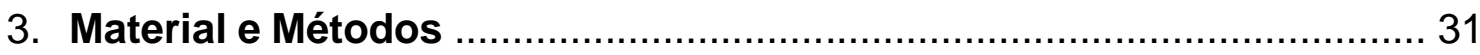

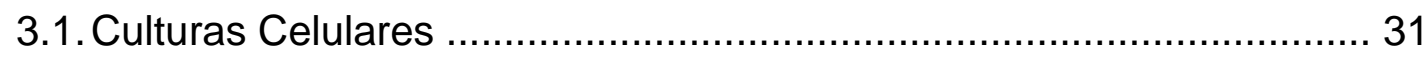

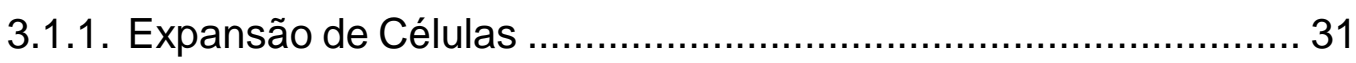

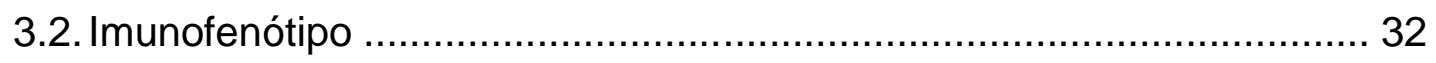

3.3. Diferenciação Osteoblástica in vitro ................................................... 32

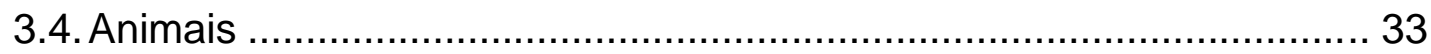

3.4.1. Associação das Células-Tronco ao Biomaterial .......................... 33

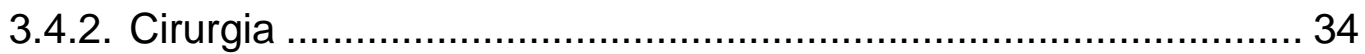

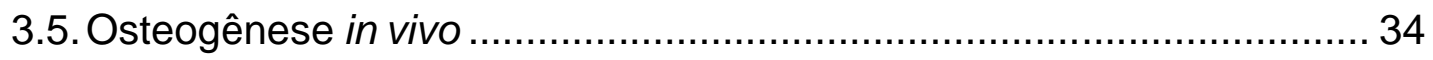

3.5.1. Localização e Avaliação da Contribuição das Células-Tronco no Início da Neoformação Óssea in vivo ............................................ 35

3.6. Micro Tomografia Computadorizada (micro-CT) ……......................... 35

3.7. Análise Histológica com Coloração de Hematoxilina e Eosina ............... 38

3.8. Análise Histológica por Fosfatase Ácida Tartarato- Resistente ............. 38

3.9. Imunohistoquímica - Detecção de Núcleo Humano ............................... 38

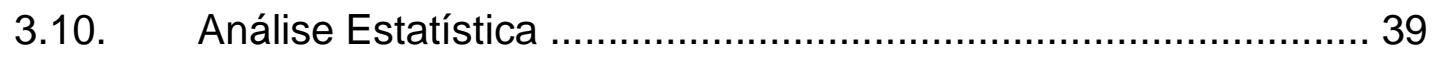




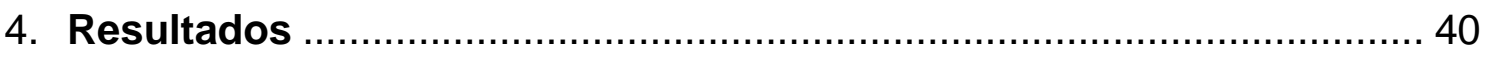

4.1. Caracterização Imunofenotípica de SHED e OOMDSC ........................ 40

4.2. Diferenciação Osteoblástica de SHED e OOMDSC in vitro .................. 41

4.3. Diferenciação Osteogênica de SHED e OOMDSC in vivo ..................... 44

4.3.1. Análise da Neoformação Óssea por Histologia ............................ 44

4.3.2. Quantificação da Neoformação Óssea por micro-CT ................... 46

4.4. Avaliação in vivo da Contribuição das Células-Tronco Humanas no Osso

Neoformado aos 50 dias Após a Cirurgia ............................................ 48

4.5. Avaliação Tempo Dependente do Potencial osteogênico das células-

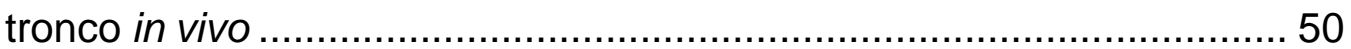

4.5.1. Análise Histológica ............................................................ 50

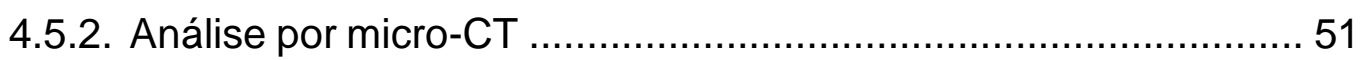

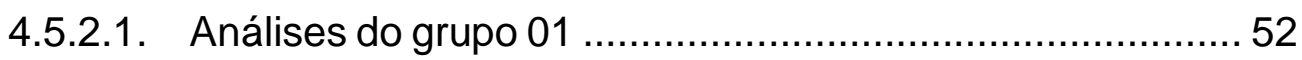

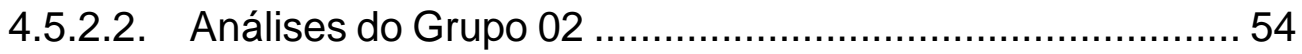

4.5.2.3. Análise de Osteoclastos no Processo de Neoformação

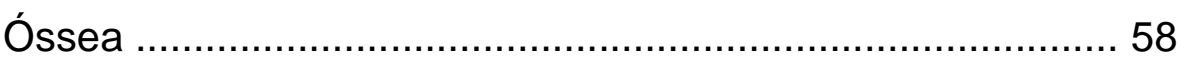

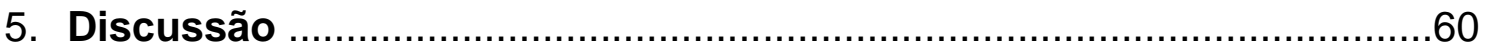

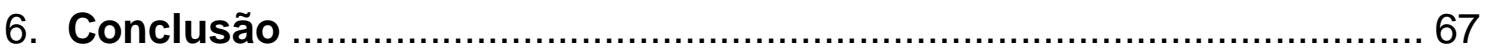

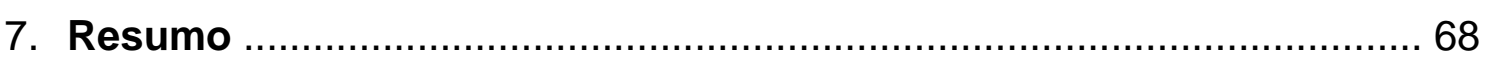

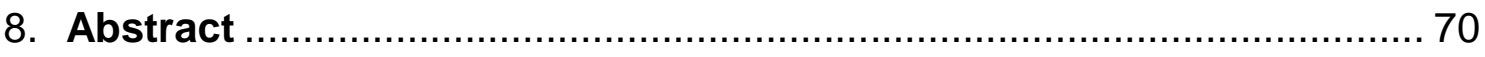

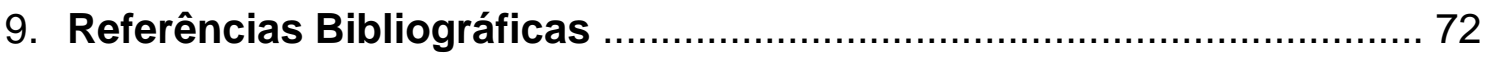




\section{Introdução}

O campo da ortopedia desenvolveu-se significativamente a partir do último século, graças ao surgimento de novos produtos, técnicas cirúrgicas e o desenvolvimento da medicina regenerativa. Entretanto, mesmo com todos estes avanços, milhões de pacientes ainda sofrem com doenças ou fraturas ósseas. Por conta disto, os processos relacionados à regeneração óssea tem recebido grande atenção da comunidade médico-científica (SEONG et al., 2010).

A medicina regenerativa é uma área extremamente ampla, que tem o objetivo de criar, reparar ou promover a regeneração de tecidos ou órgãos danificados, restaurando a arquitetura nativa e função biológica, a partir da utilização de células-tronco (CORSI et al., 2007; GLOTZBACH et al., 2011).

\subsection{Sistema Esquelético e Regeneração}

\subsubsection{O Osso}

O sistema ósseo-articular (sistema esquelético) é composto por ossos e articulações. Apresenta funções de proteção para órgãos vitais e para o canal raquidiano, proporciona a sustentação e ancoragem de músculos, além de alta atividade metabólica servindo de reserva de diversos íons, principalmente o cálcio e fosfato, liberando-os de maneira controlada na corrente sanguínea para manter a homeostase (TORTORA et al., 2010).

A partir de uma análise macroscópica, podemos distinguir os ossos compactos dos ossos esponjosos. O osso compacto ou cortical é formado por lamelas ósseas paralelas e justapostas, constituindo uma substância dura e compacta que confere resistência ao osso. O osso esponjoso ou trabecular é muito menos espesso, já que é formado por lâminas ósseas irregularmente dispostas nos vários sentidos, deixando espaços livres entre si. Entretanto, vale ressaltar que a descrição acima trata-se de uma classificação macroscópica, 
uma vez que tanto os ossos corticais quanto trabeculares apresentam a mesma estrutura histológica básica (ROSS et al., 2012).

Os ossos são compostos majoritariamente pelo tecido ósseo. Este por sua vez, é composto de três componentes principais: (1) uma matriz orgânica constituída basicamente por colágeno e outros tipos de proteínas (glicoproteínas, proteolipídeos e fosfoproteínas), (2) uma matriz mineral formada em sua maioria por cristais de fosfato de cálcio similares à hidroxiapatita e (3) pelos três componentes celulares: os osteoblastos, os quais são responsáveis pela formação óssea e pela deposição de matriz óssea; os osteócitos, responsáveis pela manutenção da massa e da estrutura óssea e os osteoclastos, os quais são responsáveis pela reabsorção da matriz extracelular óssea e mobilização de íons de cálcio e fosfato da matriz extracelular óssea para a corrente sanguínea (ROSS et al., 2012; Bab et al., 2012).

A matriz extracelular (MEC) do tecido ósseo é muito mais do que uma estrutura mecânica que serve de apoio às células ósseas. Ela tem sido reconhecida também como reguladora da atividade biológica do osso. A MEC serve como depósito de sinais moleculares, principalmente fatores de crescimento sequestrados pelos seus componentes macromoleculares (TUAN, 2013). A MEC é composta principalmente de proteínas fibrosas de colágeno com capacidade de ser mineralizada. Neste processo de mineralização, íons de cálcio e fosfato são ligados ao colágeno I e II, por ação das sialoproteínas ósseas e fosfatases alcalinas (ALP) (CHEN et al., 2012). O tecido ósseo também contém água em sua formação, o que confere resistência e flexibilidade à MEC e que por fim, refletem na sua função mecânica (CURREY, 2002).

O desenvolvimento ósseo ocorre por dois principais mecanismos: formação óssea intramembranosa e formação óssea endocondral. A formação óssea intramembranosa é o processo formador da maioria dos ossos do crânio, tais como: frontal, parietal, de partes do occipital e temporal e das maxilas superior e inferior. Além de contribuir para o crescimento dos ossos curtos e o crescimento em espessura dos ossos longos. Este processo de formação óssea é mediado pela porção interna do periósteo. Nele as células-tronco mesenquimais se diferenciam em osteoblastos, e estes por sua vez, sintetizam 
o osteóide (matriz ainda não mineralizada) que logo se mineraliza. Neste processo alguns osteoblastos ficam aprisionados nos espaços lacunares e passam a ser osteócitos (SHAPIRO, 2008; TETI, 2011).

A formação óssea endocondral é a responsável pela formação dos ossos curtos e longos. Ela tem início sobre um molde de cartilagem hialina. A ossificação endocondral consiste essencialmente em dois processos. Primeiro, o molde de cartilagem hialina sofre uma série de modificações: hipertrofia dos condrócitos, produção de colágeno $X$ e morte dos condrócitos por apoptose. Segundo, as cavidades deixadas pelos condrócitos são invadidas por capilares sanguíneos e por células-tronco mesenquimais oriundas dos tecidos adjacentes. Finalmente, estas células-tronco mesenquimais se diferenciam em osteoblastos, os quais produzirão a matriz óssea sobre os restos da cartilagem hialina. Ao produzir a matriz óssea acabam ficando retidos e passam a ser osteócitos (TETI, 2011).

A ossificação endocondral inicia com o aparecimento dos centros de ossificação primários ainda no estágio embrionário e se estende à diversas regiões após o nascimento. Os centros de ossificação primários iniciam a formação da diáfise dos ossos longos e são seguidos pelo aparecimento dos centros de ossificação secundário ou lamelar, os quais ocorrem nas extremidades das epífises, somente após o nascimento. A diáfise é separada de ambas as epífises pelas lâminas epifisárias, as quais são formadas por cartilagem hialina altamente especializada. A lâmina epifisária proporciona o crescimento longitudinal dos osso longos até que os indivíduos alcancem a maturidade esquelética (18 a 25 anos). Nesta fase, com exceção das cartilagens articulares, toda a cartilagem remanescente é substituída por osso (TETI, 2011).

Em ambos os processos de formação óssea, primeiramente é formado um osso imaturo, o qual é denominado de tecido ósseo primário. Neste tecido, as fibras colágenas estão desorganizadas e apresentam baixa resistência mecânica. O tecido ósseo primário é gradativamente substituído pelo tecido ósseo secundário ou lamelar. Este por sua vez, apresenta organização lamelar concêntrica altamente organizada, em que as fibras de colágeno estão dispostas 
paralelas umas às outras na mesma lamela, conferindo ao osso resistência à torção (SHAPIRO, 2008; TETI, 2011).

\subsubsection{Regeneração Óssea}

O tecido ósseo é um tecido dinâmico que está em constante remodelamento através de um processo de reabsorção e síntese mediados por osteoclastos e osteoblastos, respectivamente (BAR-SHAVIT, 2008). O remodelamento ósseo promove ajustes morfológicos, a reparação de microfraturas e garante a homeostase mineral. Estima-se que 3\% do osso cortical humano e mais de $30 \%$ do osso trabecular são remodelados por ano, e isto responderia a $6 \%$ dos ossos sendo remodelados anualmente (JIMI et al., 2012).

As fraturas são situações que levam à descontinuidade do osso. Em geral, o osso apresenta elevada capacidade de regeneração após fraturas, mesmo em indivíduos adultos. O processo natural de regeneração de uma fratura começa quando o osso lesionado e tecidos circundantes sangram e formam um hematoma na região. A formação do hematoma geralmente é seguida por uma resposta inflamatória. É durante esta fase que ocorre a degranulação plaquetária e a infiltração de macrófagos no local da fratura, os quais liberam citocinas inflamatórias incluindo fatores de crescimento derivados de plaquetas (PDGF), fatores transformadores de crescimento $\beta$ (TGF- $\beta$ ), interleucinas 1 e 6 (IL-1 e IL-6), prostaglandina E2 (PGE2) e fator de necrose tumoral a (TNF- $\alpha$ ). Ainda nesta fase inicial, fibroblastos e células-tronco (CT) começam a se proliferar e expressar fatores de crescimento fibroblásticos (FGF), além disso, as CTs e as células osteoprogenitoras começam a expressar proteínas morfogenéticas ósseas (BMP) e TGF- $\beta$ necessários na via de maturação dos pré-osteoblastos em osteoblastos e também para a formação óssea (BORRELLI et al., 2012).

Em seguida, com a maturação do hematoma uma matriz colágena e vasos sanguíneos se desenvolvem e a partir desta vascularização, nutrientes, fatores de crescimento e mais CTs são direcionadas ao local e promovem a regeneração da lesão (BORRELLI et al., 2012; HOLZAPFEL et al., 2013). Entretanto quando 
se trata de lesões muito grandes, ocorre uma invasão de tecido fibroso que pode preencher o espaço do defeito e impedir a formação da vascularização. Consequentemente, o processo de regeneração do osso é interrompido e não leva à união das estruturas (ZHANG et al., 2012). Nestes casos, as lesões que não se regeneram espontaneamente ainda permanecem como um desafio clínico e são denominadas de defeitos críticos (GIANNOUDIS et al., 2007; SCHMITZ, 1986).

Os defeitos críticos geralmente se originam de traumatismos ósseos seguidos ou não de infecção, tumores, periodontite, síndromes e malformações congênitas, podendo resultar em sequelas funcionais e estéticas graves (PAGNI et al., 2012). Nos casos das malformações craniofaciais, como por exemplo as fissuras lábio-palatinas, o osso ausente deve ser reposto cirurgicamente por enxertos ósseos para estabelecer a continuidade da esqueleto craniofacial. Além disto, nestes casos a reabsorção óssea ocorre de 10 a $36 \%$ dos casos, nas quais são necessárias outras intervenções cirúrgicas (BAYERLEIN et al., 2006; HIBI et al., 2006).

\subsubsection{Enxertos Ósseos}

Os procedimentos clínicos para o tratamento das fraturas ósseas devem se basear não só na localização da lesão mas também na necessidade e idade de cada paciente (HOLZAPFEL et al., 2013). Atualmente, o padrão ouro para a reconstrução óssea são os enxertos autólogos, os quais utilizam sítios doadores do próprio paciente como por exemplo a crista ilíaca, costelas, calvária, tíbia entre outros. Este método fornece três elementos essenciais: um substrato osteocondutor, fatores osteoindutores e células osteogênicas. No entanto, ele também apresenta algumas desvantagens tais como: a necessidade de um segundo sítio cirúrgico para a obtenção do enxerto, quantidade limitada de osso que pode ser retirada; morbidade da área doadora; reabsorção pósoperatória; além de complicações como dor crônica e lesões vasculares durante o procedimento cirúrgico (ABUKAWA et al., 2006). 
Uma alternativa para realização dos enxertos autólogos é a utilização de osso alogênico obtido de bancos de ossos, o que pode eliminar as desvantagens citadas acima. Uma vez que os indivíduos são geneticamente diferentes, os tecidos ósseos substituintes precisam ser tratados para reduzir a rejeição. Este tratamento impossibilita sua participação na fase osteogênica do reparo ósseo, mas preserva as características osteocondutoras e osteoindutoras do enxerto, conferindo-Ihe uma matriz sobre a qual ocorrerá a angiogênese e a osteogênese a partir das células mesenquimais do tecido conjuntivo (PINTO, 2010). Entretanto, o processo de desvitalização e a consecutiva absorção do enxerto podem levar a uma perda da estabilidade mecânica e a falhas na integração com o osso do paciente. Além disto, devido à natureza compacta dos ossos corticais alogênicos, o processo de revascularização e invasão celular podem não ocorrer. Portanto acredita-se que a falta de remodelamento e de revascularização podem ser responsáveis pela alta taxa de complicações cirúrgicas desta metodologia (DIMITRIOU et al., 2011).

A estas limitações somam-se a crescente demanda de transplantes alogênicos e a limitada quantidade de osso que podem ser retiradas dos sítios doadores nos transplantes autólogos. Diante disto novos conceitos terapêuticos tem sido idealizados para substituir as atuais opções de tratamento que utilizam abordagens inertes. Estas novas abordagens, agora com enfoque mais biológicos focalizam na reconstrução estrutural-funcional dos tecidos. Foi neste contexto que emergiu a bioengenharia de tecidos ósseos, uma ciência que oferece soluções a serem implementadas no campo da medicina regenerativa (HOLZAPFEL et al., 2013).

\subsection{Bioengenharia do Tecido Ósseo}

A bioengenharia de tecido ósseo é uma ciência interdisciplinar que aplica princípios de engenharia e de ciências biológicas para a produção de tecidos ósseos. Os esforços são voltados fundamentalmente para a compreensão da relação estrutura-função, tanto em tecidos ósseos saudáveis quanto nos que apresentam alguma patologia, além do desenvolvimento de substitutos 
biológicos para a restauração ou promoção da regeneração (CHAPEKAR, 2000). Para desenvolver estes substitutos biológicos a bioengenharia de tecido ósseo se baseia em três princípios: células-tronco, biomateriais com capacidade osteocondutivas e fatores de crescimento que induzem a formação óssea (LANGER; VACANTI, 1993). Cada um destes elementos, quando utilizados sozinhos, são capazes de promover a regeneração do osso, entretanto, quando utilizados em combinações ou todos ao mesmo tempo o resultado é melhor (EBERLI et al., 2011).

Desde a descrição da bioengenharia de tecidos por LANGER e VACANTI em 1993, diversas estratégias para o desenvolvimento da bioengenharia de tecido ósseo foram exploradas. Estas por sua vez podem ser classificadas de acordo com suas abordagens: metodologias que utilizam fatores de crescimentos ou técnicas que utilizam CTs com potencial osteogênico (MEINEL et al., 2004).

As abordagens que utilizam CTs exógenas dependem dos fatores de crescimento secretadas por elas para potenciar o processo de reparo do defeito. Em contraste, as técnicas que utilizam fatores de crescimento exógenos mobilizam as células osteoprogenitoras do hospedeiro para o local da lesão e as induzem a se diferenciar para promover a regeneração óssea (KIMELMAN et al., 2007).

A escolha da melhor abordagem ainda é muito controversa. Enquanto as técnicas baseadas em fatores de crescimento podem disponibilizar imediatamente estes fatores no sítio a ser regenerado, sua eficiência é altamente dependente do pool de células osteogênicas endógenas, as quais podem estar comprometidas devido a uma variedade de doenças ou pela idade do paciente. Além disto, são necessárias várias aplicações de fatores de crescimento em concentrações otimizadas de acordo com cada etapa da via de regeneração (ROUWKEMA et al., 2008).

Por outro lado, as abordagens que utilizam CTs exógenas funcionam independentemente das células osteogênicas do hospedeiro, e podem, portanto, alcançar um melhor resultado clínico em pacientes com células progenitoras 
osteogênicas comprometidas tanto pela idade avançada como por alguma patologia (ZHANG et al., 2012).

Portanto, em vista destas razões optamos no presente estudo por abordar dois dos três princípios da bioengenharia de tecidos ósseos: as células-tronco e os biomateriais.

\subsubsection{Noções Básicas da Biologia das Células-Tronco.}

O termo células-tronco (CT) refere-se a uma população de células indiferenciadas que apresentam grande capacidade proliferativa, de autorenovação e de se diferenciarem em uma variedade de tipos de células especializadas (plasticidade) sob condições apropriadas (LAJTHA, 1979). As CTs são categorizadas de acordo com sua origem (embrionárias e adultas) e plasticidade (FIG. 01).

As células-tronco embrionárias (CTEs) são obtidas da massa celular interna do blastocisto (entre 4 ou 5 dias após a fecundação), e já foram isoladas de embriões de camundongos, ratos e de humanos (BUEHR et al., 2008; EVANS, 1981; THOMSON et al., 1998). As CTEs possuem a característica de se auto-renovar in vitro, enquanto perdurar o contato com o feeder cell layer. Uma vez cessado este contato elas iniciam o processo de diferenciação resultando na formação de agregados tridimensionais de células, denominados de corpo embrióides, seguido da diferenciação para regiões derivadas das três camadas germinativas: endoderma, mesoderma e ectoderma (SEONG et al., 2010).

No entanto, alguns problemas quanto a utilização das CTEs em terapia tem sido levantados na literatura. Entre eles podemos destacar a formação de teratomas, a rejeição imunológica e problemas éticos (SWIJNENBURG et al., 2005; WINKLER et al., 2005). 


\section{Box 1 - Noções básicas da biologia das células-tronco}

Células-tronco: células com a capacidade de auto-renovação e diferenciação.

Nichos: Microambiente celular oferecendo apoio e estímulos para controlar as propriedades de células-tronco.

Auto-renovação: Divisão celular assimétrica a qual pelo menos uma célula filha é igual ao célula-mãe.

Comprometimento: Envolvimento numa via definida que conduz à diferenciação e a incapacidade para a auto-renovação.

Célula progenitora: Uma célula proliferativa, com a capacidade de se diferenciar, mas sem a capacidade de auto-renovação.

Totipotência: capacidade em dar origem a todas as células de um organismo adulto incluindo os tecidos extraembrionários. Exemplo: zigoto.

Pluripotência: célula-tronco que possui o potencial de se diferenciar em qualquer uma das camadas germinativas. Exemplo: Célula-tronco embrionária.

Multipotência: capacidade de gerar um número limitado de células especializadas, geralmente com especificidade para uma das camadas germinativas. Exemplo: células-tronco adultas.

Oligopotência: Capacidade de formar duas ou mais tipos de células num tecido. Exemplo: as células-tronco neuronais, com capacidade para formar diferentes tipos de neurônios.

Unipotência: Capacidade de formação de um tipo de célula. Exemplo: espermatogônias.

Figura 01. Noções básicas de células-tronco.

Após o estágio de blastocisto do embrião, as CTEs não são mais encontradas e a regeneração e formação dos tecidos passa a ser mantida por diferentes populações de células-tronco adultas (CTA) (GLOTZBACH et al., 2011). 
As CTAs residem em locais anatômicos específicos denominados nichos, os quais criam microambientes únicos. Cada nicho tem um papel dominante no controle do comportamento das CTs. Os sinais a partir do nicho influenciam na proliferação das CTs e também ajudam a manter o seu estado indiferenciado. As CTAs podem ser encontradas na maioria dos tecidos de todo o organismo (FIG. 02) e elas apresentam uma notável capacidade de se auto-renovar ou de se diferenciar a um (unipotência) ou mais (multipotência) tipos celulares (HSU, 2012).

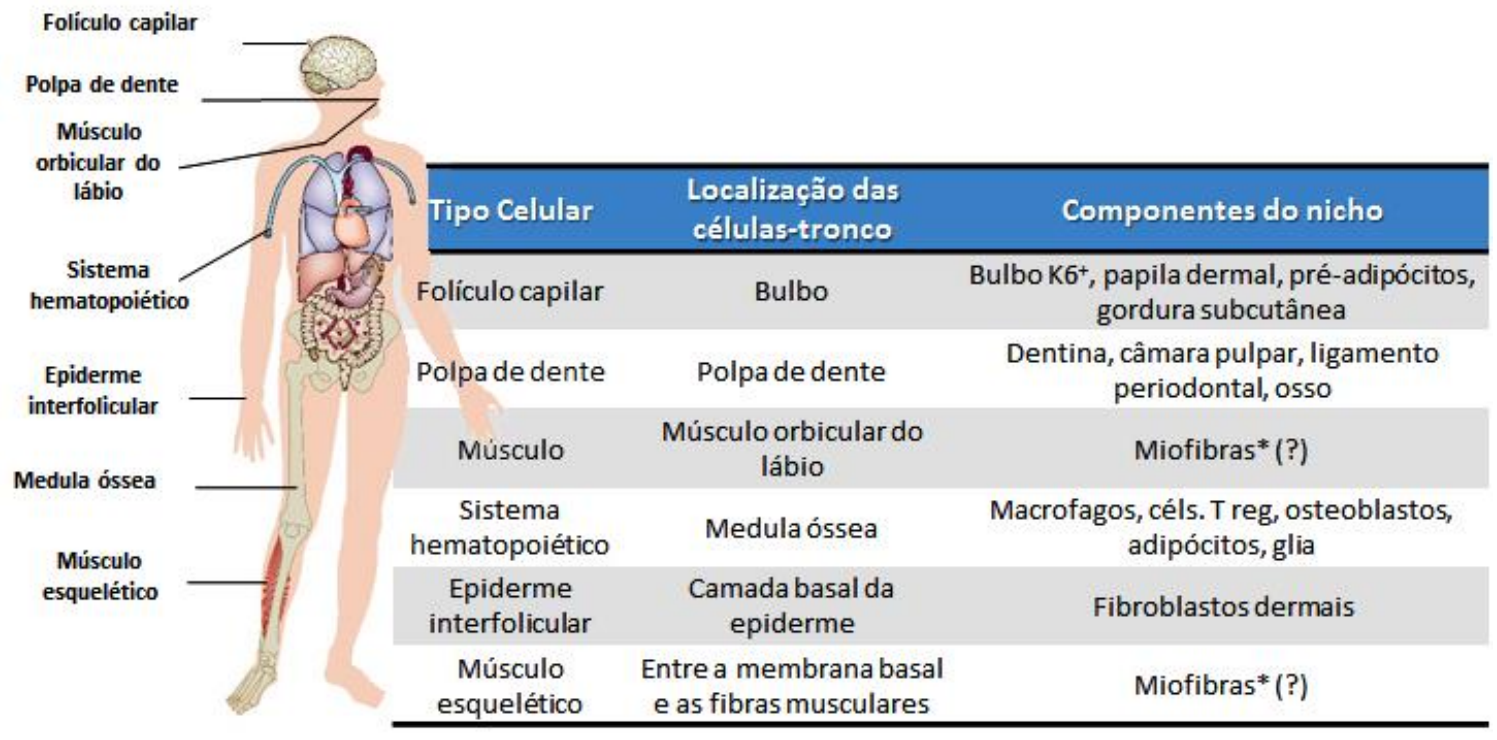

Figura 02. Localização de algumas células-tronco adultas (CTA). As CTAs são células indiferenciadas encontradas em diversos tecidos do corpo. Elas apresentam tanto a capacidade de auto-renovação e de se diferenciarem em tipos celulares especializados sob apropriadas condições. A localização de algumas células-tronco (CT) e seus respectivos nichos estão listados na tabela. Os componentes do nicho que são derivados das CTs estão marcados com asterisco $\left({ }^{*}\right)$; os pontos de interrogação (?) indicam candidatos a componentes do nicho cujo o papel regulador ainda precisam ser demonstrados; K6: queratina 6; céls. T reg: células T reguladoras. Figura adaptada de (HSU, 2012).

A atividade das CTAs podem variar bastante dependendo dos tecidos em que se encontram. Por exemplo, grande parte das células da epiderme, do intestino e do sistema hematopoiético morrem diariamente como parte do seu ciclo de vida normal, assim a regeneração destes tecidos necessitam do constante uso das CTAs (HSU, 2012). Entretanto, a grande maioria das CTAs 
permanecem em relativa quiescência, mas em períodos de estresse ou quando ocorre uma lesão elas são rapidamente mobilizadas.

As CTAs tornaram-se o foco de pesquisas na área da medicina regenerativa devido às características acima citadas e pela possibilidade de serem utilizadas em terapias (GLOTZBACH et al., 2011).

\subsubsection{Células-Tronco Mesenquimais}

Existem três tipos de subpopulações de CTAs: as células-tronco hematopoiéticas, as endoteliais e as mesenquimais. As células-tronco mesenquimais (CTM) compreendem uma subpopulação de células multipotentes capazes de gerar o mesênquima, ou seja, tecidos que se desenvolvem principalmente a partir da mesoderme do embrião (CAPLAN, 1991).

As CTMs apresentam grande potencial em aplicações clínicas devido ao fácil isolamento e manipulação, à sua capacidade de serem expandidas ex vivo e de se diferenciarem em diversas linhagens, incluindo osteócitos, condrócitos, miócitos e adipócitos (RUBIO et al., 2005). De acordo com a Sociedade Internacional de Terapia Celular, as CTMs devem apresentar além da multipotência, aderência ao plástico e imunofenótipo específico: mais de 95\% da população devem apresentar marcação positiva para os antígenos de superfície CD13, CD29, CD44, CD73, CD105 e CD166 e menos de 3\% de marcação negativa para CD11, CD14, CD31, CD34, CD45 (DOMINICl et al., 2006).

As CTMs são as responsáveis pela capacidade regenerativa dos seus tecidos adjacentes. Elas já foram isoladas em diversos tecidos como: a medula óssea, tecido adiposo, periósteo, membrana sinovial, músculo esquelético, derme, sangue, cordão umbilical humano, pulmão, trompa de falópio, polpa de dente, músculo orbicular do lábio (BUENO et al., 2009; DE BARI et al., 2001; DE MENDONÇA COSTA et al., 2008; FRIEDENSTEIN et al., 1966; GRONTHOS et al., 2000; IN 'T ANKER et al., 2003; JANKOWSKI; DEASY, 2002; JAZEDJE et 
al., 2012; MARESCHI et al., 2001; NAKAHARA et al., 1990; SECCO et al., 2009; TOMA et al., 2001; ZUK et al., 2001; ZVAIFLER et al., 2000).

Dentre as CTMs, as CTs provenientes da medula óssea (BMSC) vêm sendo amplamente utilizadas em estudos pré-clínicos e clínicos (CAPLAN, 2009). Embora o uso das BMSCs tenha demonstrado bons resultados clínicos na bioengenharia do tecido ósseo, o processo para obtenção destas células é invasivo e doloroso, assim como o processo de obtenção de osso autógeno. As BMSC, correspondem a uma população de células escassas $(0,01 \%$ a $0,001 \%$ das células isoladas). Além disto, a sua multipotência e capacidade de reparo de tecidos e órgãos são inversamente proporcionais à idade do doador (CHOUDHERY et al., 2012; PITTENGER et al., 1999; SEONG et al., 2010). Sendo assim é importante identificar outras fontes de CTs com potencial osteogênico e que possam ser obtidas de maneira menos invasivas. Diante destes fatores, optamos em estudar as células-tronco de dentes decíduos esfoliados e as células-tronco do músculo orbicular do lábio, que apresentam características promissoras para utilização na bioengenharia de tecido ósseo.

\subsection{Células Tronco de Dentes Decíduos Esfoliados}

Uma fonte alternativa de CTs para aplicações na bioengenharia de tecido ósseo provém da polpa de dente decíduos. Estes dentes são eliminados naturalmente como parte do desenvolvimento da dentição de cada pessoa ou por intervenções de cirurgiões dentistas como parte do tratamento odontológico (SONOYAMA et al., 2008).

As células-tronco de dentes decíduos esfoliados (SHED) apresentam propriedades típicas de $\mathrm{CT}$, e uma taxa de proliferação maior em relação as células-tronco de polpa de dente adultas (DPSC) e da medula óssea (BMSC), facilitando assim a sua expansão in vitro antes da implantação em biomateriais (MIURA et al., 2003). Ainda neste contexto, estudos anteriores mostram que do ponto de vista osteoblastogênico as SHED apresentam potencial idêntico ao das BMSC, tanto em análises in vitro como em in vivo, e podem ser uma fonte alternativa de CT para serem usadas na bioengenharia de tecido ósseo, 
particularmente no tratamento das malformações craniofaciais (SEO et al., 2008; TAMAKI et al., 2012; YAMAZA et al., 2010). Além disto um estudo realizado pelo nosso grupo observou que SHED apresenta maior potencial osteogênico do que células-tronco de tecido adiposo (ADSC), tanto in vitro como in vivo. Neste estudo, as SHED apresentaram elevada atividade de fosfatase alcalina e de mineralização da matriz extracelular quando comparadas com ADSC. E ainda quando comparado o potencial de neoformação óssea in vivo em defeitos críticos calvarianos em ratos não imunossuprimidos, as SHED induziram 7 vezes mais formação óssea do que as ADSC (Fanganiello et al., manuscrito em preparação).

Estudos que verificam o potencial osteogênico das SHED in vivo geralmente associam estas células à biomateriais e em seguida, as implantam tanto em compartimentos subcutâneos no dorso de animais, quanto em defeitos críticos. Contudo, a origem da neoformação óssea é um ponto controverso e que merece ser discutido em detalhes. Como relatado na literatura, as ilhas ósseas podem ter origem nas células enxertadas, ser de origem do hospedeiro ou ainda ser um mosaico contendo células tanto do hospedeiro quanto enxertadas.

MIURA e colaboradores (2003) associaram SHED à biomateriais de HA/ $\beta$ TCP e enxertaram em compartimentos subcutâneos de camundongos imunossuprimidos. Após 8 semanas eles observaram a formação de ilhas ósseas no interior dos poros do biomaterial. Para verificar a origem da neoformação óssea, eles utilizaram sondas especificas para sequência Alu humanas e observaram que as células humanas estavam localizadas no tecido conjuntivo que preenchia os poros do biomaterial, enquanto que as ilhas ósseas foram marcadas com sondas específicas para a sequência Pf1 murinas. Entretanto, resultado oposto, foi observado por LAINO e colaboradores (2006) quando enxertaram SHED em compartimento subcutâneo de ratos imunossuprimidos. Neste estudo eles observaram que após 4 semanas o osso neoformado era de origem humana, porém estes pesquisadores pré-induziram as SHED antes das cirurgias, e isto pode ter selecionado uma subpopulação de células mais comprometidas com a diferenciação osteogênica, o que explicaria as diferenças entre ambos os estudos. 
Por outro lado, os trabalhos que verificaram a regeneração de defeitos críticos calvarianos em camundongos imunossuprimidos observam que as SHED são responsáveis pela neoformação óssea (MA et al., 2012; SEO et al., 2008). E ainda, quando os defeitos críticos são em mandíbulas de porcos, foi demonstrado que osso neoformado nesta região tinha como origem tanto as células enxertadas como as células do próprio hospedeiro (ZHENG et al., 2009).

Recentemente, o nosso grupo utilizou SHED associadas a biomateriais de membrana de colágeno para regenerar defeitos críticos na calvária de ratos Wistar não imunossuprimidos. Após 60 dias de implantação, foi verificado que nos lados enxertados com SHED o defeito crítico havia sido regenerado. Neste estudo foram coletados DNAs tanto do lado controle quanto do lado contendo as SHED, e a partir da técnica de PCR, o DNA humano foi detectado apenas nos lados contendo as SHED e a origem das ilhas ósseas neoformadas foi atribuída às células humanas (DE MENDONÇA COSTA et al., 2008).

Portanto, estes dados na literatura sugerem que se o modelo animal for imunossuprimidos, as SHED se diferenciarão em osteoblastos. Caso contrário, o osso neoformado poderá ser tanto um mosaico formado pelas células enxertadas ou ser de origem do hospedeiro. Além disto, outros pesquisadores sugerem que as CTs enxertadas são responsáveis por recrutar as células osteoprogenitoras do hospedeiro, secretar fatores de indução à osteogênese para que as células osteoprogenitoras se diferenciem em osteoblastos (BONFIELD et al., 2010; MIURA et al., 2003). Desta forma, estudos que esclareçam a origem das neoformações ósseas em modelos de xenotransplantes precisam ser melhor debatidos.

\subsection{Células-Tronco Derivadas de Músculo}

O tecido muscular contém uma população de células heterogêneas. Esta população inclui além da fibras musculares, células-tronco derivadas de músculo (MDSC). As MDSC são células multipotentes, capazes de se diferenciar em diversos tipos celulares, tais como os adipócitos, osteoblastos e condrócitos (JACKSON et al., 2011; JANKOWSKI et al., 2002; MASTROGIACOMO et al., 2005; SUN et al.,, 2005). 
Recentemente, o nosso grupo identificou as células-tronco do músculo orbicular do lábio (OOMDSC), cujos fragmentos são rotineiramente descartados durante as cirurgias de reconstrução do lábio (queiloplastia) dos pacientes com fissuras lábio palatinas (FL/Ps). Estas células são de grande interesse na bioengenharia de tecido ósseo, uma vez que a sua coleta não confere morbidade adicional ao paciente e seu uso poderia contribuir para o processo de reconstrução do osso alveolar, frequentemente comprometido nestas crianças com FL/Ps.

As OOMDSC exibem as marcações de superfície celular típicas de células-tronco e são capazes de se diferenciar em adipócitos, condrócitos e osteoblastos in vitro. Quando associadas a um biomaterial à base de colágeno, promovem a regeneração de defeitos críticos calvarianos em ratos Wistar (BUENO et al., 2009).

Alguns autores sugerem que as MDSC sem modificação genética não são capazes de promover a regeneração óssea, e além disto, só a partir de estímulos por BMP-2, que as MDSC seriam capazes de se diferenciar em osso (LEE et al., 2001). De fato, a grande maioria dos estudos que verificam o potencial osteogênico das MDSC in vivo geralmente utilizam células de camundongos geneticamente modificadas para expressar BMP-2 ou BMP-4 humanas.

Além disto, alguns estudos na literatura sugerem que as neoformações ósseas podem ter como origem as MDSC enxertadas (LEE et al., 2001; MASTROGIACOMO et al., 2005; MUSGRAVE et al., 2002; WRIGHT et al., 2002) ou ainda ser um mosaico contendo porções de ambas as origens (MESZAROS et al., 2012).

LEE e colaboradores (2001) estudando a regeneração de defeitos críticos calvarianos de camundongos imunossuprimidos, isolaram células dos músculos das pernas traseiras de camundongos $\mathrm{C} 57 \mathrm{BL}$ e as modificaram geneticamente para expressar BMP-2 humano. Quatro semanas após as cirurgias, eles verificaram que as lacunas das ilhas ósseas que regeneraram o defeito crítico continham apenas $5 \%$ das células que expressavam BMP-2 humano, enquanto a grande maioria estava localizada às margens das ilhas ósseas ou no tecido 
conjuntivo. Ou seja, uma pequena porcentagem das MDSC não só participaram com um veículo de entrega de BMP-2 como também diferenciaram em osteoblastos e ajudaram no reparo do defeito crítico.

MESZAROS e colaboradores (2012) estudando a influência do gênero do hospedeiro na regeneração óssea, isolaram MDSC de camundongos C57BL e as modificaram geneticamente para expressar tanto BMP-4 humano como GFP. Em seguida, as enxertaram em defeitos críticos tanto de machos como de fêmeas de camundongos C57BL. Após 28 dias de cirurgia havia se formado mais osso nos hospedeiros machos quando comparados com hospedeiras fêmeas. Além disto, a partir da detecção das células que expressavam GFP, foi possível determinar a contribuição das MDSC na neoformação óssea. Como observado, as ilhas ósseas eram formadas tanto pelas células enxertadas e em maior proporção por células do hospedeiro.

Contudo, apesar das MDSC serem de fácil acesso e obtenção, até o momento existem apenas dois trabalhos que utilizam estas células isoladas de tecidos humanos (BUENO et al., 2009; GAO et al., 2012) sendo que em nenhum deles é comparado o potencial de diferenciação osteogênico com outras fontes celulares. Além disto, com exceção do trabalho de BUENO e colaboradores (2009), todos os demais trabalhos modificam geneticamente as MDSC. Em razão disso é de grande importância um trabalho que compare as MDSC, sem modificação genética, com uma outra fonte celular e se a neoformação óssea in vivo é de origem das células enxertadas ou do hospedeiro.

\subsubsection{Biomateriais}

$\mathrm{Na}$ bioengenharia de tecido ósseo utilizam-se biomateriais, os quais mimetizam a MEC para que as células tenham a possibilidade de se aderirem, proliferarem, e diferenciarem para regenerar o tecido (VAN HOUT et al., 2011).

No que diz respeito aos biomateriais utilizados como arcabouços, não há como rotina o uso de um modelo único de estrutura que seja aplicável a todas as situações, fazendo-se necessária a busca e o desenvolvimento de materiais alternativos com características osteogênicas, osteoindutivas, osteocondutivas e 
osteointegrativas para que ocorra a regeneração óssea (SITTINGER et al., 2004).

Os biomateriais desempenham um papel fundamental fornecendo um modelo tridimensional para a neoformação óssea. Os biomateriais não só podem ser usados como veículos para a entrega das CTs, mas também podem servir como um microambiente sintético em termos de composição química, estrutura física e com porções biologicamente funcionais (PAGNI et al., 2012)

Segundo POTTER e ELLIS (2004), um biomaterial ideal para enxerto ósseo deve conter as seguintes propriedades: ser quimicamente inerte, biocompatível, não alérgico, não cancerígeno, de custo aceitável, passível de esterilização sem que haja alteração de sua composição química, de fácil manipulação, de fácil conformação durante a realização da cirurgia, de boa estabilidade e apresentar radiopacidade. Além disso, o biomaterial não deve ser uma fonte passível de crescimento bacteriano. Finalmente, o material deve ser totalmente reabsorvível e substituível por tecido ósseo novo.

Muitos materiais tem sido utilizados para confecção dos biomateriais para bioengenharia de tecido ósseo como: materiais sintéticos (polyesters derivados de $\alpha$-hridroxiacidos e outros polímeros) (STARK et al., 1998) a associação de cerâmicas com fosfato de cálcio e moléculas bioativas (HUTMACHER, 2000); uso de polímeros naturais como: colágenos, proteoglicanas, glicosaminoglicanas, elastinas e hidroxiapatita (LEE et al., 2001; STARK et al., 1998).

Biomateriais de cerâmicas de fosfato de cálcio, como os de hidroxiapatita (HA) e de tricálcio fosfato (TCP) são frequentemente utilizados para a regeneração óssea devido a sua semelhança com a porção mineralizada do osso (EL-GHANNAM, 2005). Tanto a HA e TCP são biocompatíveis e osteocondutivos, porém apresentam algumas desvantagens. Estudos anteriores revelaram que as partículas de HA é um arcabouço para a neoformação óssea, no entanto, apresenta baixa reabsorção. Em contraste a TCP tem reabsorção imprevisível (DACULSI et al., 2003). À partir da fabricação de um composto cerâmico bifásico a base de $60 \%$ HA e $40 \%$ B-TCP foi possível controlar a 
reabsorção do material e ao mesmo tempo manter a sua propriedade osteocondutora (PLACHOKOVA et al., 2007).

A presença de poros interconectados na estrutura do biomaterial é fundamental para a formação óssea, pois permite a migração de células dos tecidos adjacentes e a angiogênese. $O$ diâmetro dos poros também deve ser levado em consideração, poros muito pequenos levam a uma migração celular limitada e impedem a vascularização, resultando na formação de uma cápsula celular fibrosa envolvendo o biomaterial (HARLEY et al., 2008). Em contraste, poros muito grandes podem afetar as propriedade mecânicas dos biomateriais (KARAGEORGIOU \& KAPLAN, 2005). Para a bioengenharia de tecidos ósseos estima-se que os poros do biomaterial devam ter entre 100um a 900um, e em média 300um para promover a formação de vasos capilares. Poros maiores que 300um favorecem a osteogênese direta, enquanto poros menores estimulam a ossificação osteocondral (ROOSA et al., 2010; SZPALSKI et al., 2012).

Os biomateriais vêm ganhando cada vez mais aceitação no mercado em razão do fácil uso e manipulação por diminuir a morbidade do sítio doador do enxerto e diminuir o tempo da cirurgia, além de serem produzidos com uma ampla variedade de parâmetros (tamanhos, formatos, porosidades).

\subsection{Modelos animais}

Um grande desafio da bioengenharia de tecidos ósseos é identificar e validar modelos animais clinicamente relevantes de doenças humanas ou lesões. Modelos em animais de grande porte são caros e difíceis de trabalhar em grandes quantidades. Além disso, a imunologia e fisiologia geralmente não estão bem caracterizadas. Ratos, por outro lado, são ideais do ponto de vista prático, pois é possível trabalhar com grandes quantidades, além de ter a imunologia e a fisiologia bem conhecidas. (HORWITZ, 2013).

O modelo biológico mais utilizado para promoção de regeneração do tecido ósseo in vivo descrito na literatura é a reconstrução de defeitos críticos criados nas calvárias de ratos (GOMES, 2011). SCHMITZ e colaboradores 
(1986) conceituaram que um defeito de tamanho crítico, em um modelo experimental, é aquele que não irá reparar espontaneamente durante o tempo de vida do animal. No entanto, alguns autores defendem que deva ser considerado um defeito crítico aquele que não se repara até o término do estudo, uma vez que tais estudos não duram por toda vida do animal (COOPER et al., 2010; GOSAIN et al., 2000).

A escolha da calvária como modelo para mimetizar grandes perdas craniofaciais deve-se ao fato dela ser composta por osso membranoso e um suplemento sanguíneo relativamente limitado, conferindo poucas propriedades para se regenerar espontaneamente (SCHMITZ et al., 1986). Além disto é uma área anatomicamente livre de estresse mecânico e existe uma estabilidade relativa das estruturas que circundam o defeito crítico (MANKANI et al., 2006). 


\section{Objetivos Gerais}

- Verificar se as células-tronco obtidas do músculo orbicular do lábio humanos apresentam o mesmo potencial de diferenciação osteogênica do que as células tronco obtidas de polpa de dentes esfoliados in vitro e in vivo,

- Verificar se células-tronco transplantadas em ratos contribuem para o processo de neoformação óssea de calvaria

\subsection{Objetivos Específicos}

- Comparar o potencial osteoblastogênico das células-tronco de diferentes fontes após 9, 14 e 21 dias do início de diferenciação in vitro. $E$ in vivo após 50 dias pós cirúrgicos.

- Verificar em diferentes tempos pós-cirúrgicos a localização e distribuição das células-tronco implantadas em defeitos críticos calvarianos em ratos Wistar.

- Verificar se células-tronco humanas transplantadas em defeitos críticos de calvaria diferenciam e proveem a osteogênese in vivo. 


\section{Material e Métodos}

\subsection{Culturas Celulares}

Há varias evidências que mostram uma grande similaridade do potencial osteoblastogênico in vitro e in vivo entre as células-tronco mesenquimais humanas provenientes de dentes decíduos esfoliados (SHED) e as célulastronco de medula óssea (BMSC) (SEO et al., 2008; YAMAZA et al., 2010). Além disto, por se tratar de uma fonte de acesso menos invasiva, optamos em utilizar as SHED como referência ao invés das BMSC.

SHED ( $n=4)$ e células-tronco do músculo orbicular do lábio (OOMDSC) $(n=4)$ de crianças com idade entre 07 e 10 anos foram isoladas de acordo com o protocolo estabelecido em nosso laboratório (BUENO et al., 2009; DE MENDONÇA COSTA et al., 2008). A coleta destes tecidos foi aprovado pelo Comitê de Ética em Pesquisas com Seres Humanos do Instituto de Biociências da USP (processo no 104.120.09, folha de rosto no 309.839). Os termos de consentimento foram gerados por nós e assinados pelos responsáveis para a obtenção e estabelecimento das culturas de células.

\subsection{1. $\quad$ Expansão de Células}

A expansão de ambas as fontes de células-tronco foi realizada com meio de cultura DMEM F12 (Invitrogen), suplementado com 15\% de soro fetal bovino Hyclone (Thermo Scientific), $1 \%$ de antibiótico penicilina-estreptomicina $(100 \mathrm{U} / \mathrm{ml}$ de penicilina e $100 \mu \mathrm{g} / \mathrm{ml}$ de estreptomicina [Gibico/Invitrogen]) e $1 \%$ aminoácido não essenciais (Gibco/Invitrogen). O meio foi trocado a cada dois/ três dias. As culturas apresentavam morfologia fibroblastóide, aderência ao plástico e eram mantidas semiconfluentes, sendo repicadas usando $0,25 \%$ de solução de tripsina (Tryple, Invitrogen). Todas as células foram mantidas em uma estufa úmida à $37^{\circ} \mathrm{C}$ e $5 \% \mathrm{CO}_{2}$. 


\subsection{Imunofenótipo}

A caracterização dos marcadores de superfície celular tanto em SHED quanto OOMDSC foi realizada por citometria de fluxo com a ajuda do equipamento EasyCyte flow cytometry (Milipore). As células foram removidas dos frascos de cultivo usando $0,25 \%$ de solução de tripsina (Tryple, Invitrogen), peletadas e em seguida ressuspendidas com PBS (phosphate-buffered saline, $0,01 \mathrm{M}$; ph=7,4). Foram então transferidas para tubos individuais na concentração de $1 \times 10^{5}$ células $/ \mathrm{ml}$ e incubadas por uma hora à $4^{\circ} \mathrm{C}$ com os anticorpos específicos. Os anticorpos fluorescentes específicos para a detecção de células mesenquimais (CD29-PECy5, CD90-R-PE, CD73-PE e CD105-PE) (Becton Dickinson), células hematopoiéticas (CD45-FITC) (Becton Dickinson) e endoteliais (CD31-PE) (Becton Dickinson) foram utilizados. Um total de 5000 células foi analisado para cada marcador de superfície celular. Todos os dados gerados foram analisados no software Guava Express Plus (Milipore).

\subsection{Diferenciação Osteoblástica in vitro}

Triplicatas de cada uma das quatro culturas celulares provenientes de polpa de dente esfoliado e músculo orbicular do lábio foram plaqueadas $\left(15 \times 10^{3}\right.$ células $/ \mathrm{cm}^{2}$ ) em placas de 12 poços. As células foram induzidas à diferenciação com a utilização do kit de diferenciação osteogênica (StemPro®), Invitrogen). Uma outra triplicata, com as mesmas células, contendo apenas meio de cultivo, foi utilizada como controle.

A diferenciação osteoblástica foi avaliada através da quantificação da atividade da fosfatase alcalina nove dias dia após o início da indução à diferenciação. Neste período ocorre o pico da produção desta enzima, a qual é necessária para a mineralização da matriz extracelular. A atividade enzimática foi avaliada após a adição do substrato da fosfatase (Sigma-Aldrich) e quantificada colorimetricamente usando o leitor de placas Multiskan EX ELISA à 405nm (Thermo Scientific). 
Após 14 e 21 dias do início da indução à diferenciação, foi realizada a coloração por vermelho de alizarina para avaliar o acúmulo de matriz extracelular calcificada. As marcações em cada poço foram fotografadas utilizando as objetivas de 5x e 10x. Para a quantificação da matriz extracelular calcificada, foi utilizada uma solução de $20 \%$ de metanol e $10 \%$ de ácido acético para a descoloração do vermelho de alizarina. A solução colorimétrica resultante deste processo foi quantificada no espectrofotômetro no comprimento de onda de 450nm (GREGORY et al., 2004).

\subsection{Animais}

O presente trabalho foi aprovado pelo Comitê de Ética em Pesquisas com Animais do Instituto de Biociências da Universidade de São Paulo (processo no 037/060).

Utilizamos 22 ratos machos não imunossuprimidos (NIS) da linhagem Wistar com dois meses de idade e com massa corpórea de no máximo $200 \mathrm{~g}$ cada. Os animais foram comprados no biotério da Faculdade de Medicina da Universidade de São Paulo e em seguida transferidos para o biotério do Centro de Estudos do Genoma Humano da Universidade de São Paulo. Foram mantidos em estantes ventiladas (Alesco), com condições padronizadas de temperatura, arejamento e iluminação $\left(22^{\circ} \mathrm{C}\right.$, ciclagem de 12 horas de claridade por dia), com acesso livre a água e ração.

\subsubsection{Associação das Células-Tronco ao Biomaterial}

As células-tronco foram cultivadas até atingir a confluência e tripsinizadas. Utilizando o contador de células automatizado (Countess - Invitrogen), $1 \times 10^{\wedge} 6$ células foram ressuspendidas em $30 \mu \mathrm{l}$ e sobrepostas a um biomaterial cerâmico bifásico (60\% hidroxiapatita e $40 \%$-tricálcio fosfato; Cellceram Scaffdex $\left.{ }^{\mathrm{TM}}\right)$ de $4,5 \mathrm{~mm}$ de diâmetro e ficaram em contato direto com este por 1 hora. Em seguida foram adicionados $3 \mathrm{ml}$ de meio de cultura e o biomaterial contendo células foi incubado por 24 horas, até a cirurgia. 
O biomaterial apresenta em média $83 \%$ de porosidade e interconectividade entre os poros. O tamanho do poros variam ente $100-800 \mu \mathrm{m}$ e tamanho médio entre $200-400 \mu \mathrm{m}$, além disto o biomaterial pode conter algumas microporosidades.

\subsubsection{Cirurgia}

Os animais foram anestesiados com uma combinação de Ketamina hydrochoride (5\%) e xylazine (2\%) via intraperitoneal $(0,5 \mathrm{ml} / 100 \mathrm{~g}$ de peso do animal). A cabeça dos animais foi fixada em um cefalostato durante os procedimentos cirúrgicos. Uma broca trefina de $4,5 \mathrm{~mm}$ de diâmetro foi utilizada para obtenção de dois defeitos críticos cranianos os quais foram feitos na região parietal, lateralmente à sutura sagital. Este modelo já havia sido padronizado anteriormente pelo nosso grupo (Bueno et al., 2009; Yeh et al., 2012; Jazedje et al., 2012). Cumpre ressaltar que estes defeitos não se fecham espontaneamente durante o tempo do estudo.

\subsection{Osteogênese in vivo}

Os biomateriais contendo SHED, OOMDSC ou não contendo qualquer tipo celular foram enxertados nos defeitos críticos feitos nas calvarias de nove ratos Wistar. Os biomateriais foram introduzidos nos defeitos calvariais com a superfície de adição das células voltada para a duramater. Após 50 dias cirúrgicos os animais foram sacrificados em uma câmara de $\mathrm{CO}_{2}$ e as calvárias foram coletadas para análise morfológica. A relação entre a fonte celular e a quantidade de números de defeitos em que foram enxertados, está demonstrada na tabela 01.

\subsubsection{Localização e Avaliação da Contribuição das Células- Tronco no Início da Neoformação Óssea in vivo}


Para verificarmos se as ilhas ósseas são de origem humana em tempos mais precoces ou se elas estão envolvidas no processo de indução à neoformação óssea, nós associamos $1 \times 10^{6}$ células de SHED à biomateriais e utilizamos o mesmo modelo cirúrgico, conforme descrito previamente. Foram utilizados 13 animais e os grupos experimentais foram organizados de acordo com a tabela 01 abaixo.

Tabela 01: Relação entre a quantidade de defeitos críticos enxertados com SHED ou OOMDSC e os seus respectivos tempos de coleta

\begin{tabular}{ccc}
\hline \hline FONTE CELULAR & $\begin{array}{c}\text { № de } \\
\text { DEFEITOS }\end{array}$ & $\begin{array}{c}\text { TEMPO DE } \\
\text { COLETA }\end{array}$ \\
\hline SHED & 3 & 24 horas \\
SHED & 3 & 07 dias \\
SHED & 4 & 15 dias \\
SHED & 4 & 30 dias \\
SHED & 6 & 50 dias \\
OOMDSC & 7 & 50 dias \\
\hline
\end{tabular}

SHED: células-tronco de polpa de dentes decíduos esfoliados. OOMDSC: células-tronco de músculo orbicular do lábio.

\subsection{Micro Tomografia Computadorizada (micro-CT)}

Os dados obtidos de micro-CT das nossas amostras foram gerados a partir de dois equipamentos diferentes e são subdivididas em duas análises. A primeira análise (ex vivo) compreende o grupo de 09 animais sacrificados após 50 dias de cirurgia, enquanto que os dados gerados para o segundo grupo de análise são obtidos do escaneamento in vivo de 11 animais, os quais diminuem gradativamente à medida dos tempos de coleta. Vale ressaltar que em razão da utilização de equipamentos diferentes e consequentemente parâmetros de aquisição de imagem diferentes, as análises dos dois grupos não são comparáveis. 
O grupo de animais $(n=9)$ utilizados para verificarmos a formação óssea in vivo foi eutanasiado após 50 dias de cirurgia. As calotas cranianas foram removidas e fixadas em formol $4 \%$ por 24 horas. Logo após a fixação, foram submetidas à leitura por micro-CT, utilizando o equipamento Skyscan 1074 ex vivo (Skyscan, Aartselaar, Belgium), localizado no Laboratório de Metabolismo Ósseo do Departamento de Anatomia (ICB-USP). Os parâmetros de leitura configurados no equipamento foram os mesmos para cada calota e consistiram na voltagem da fonte em $50 \mathrm{kv}$, corrente elétrica em $357 \mu \mathrm{A}$, e filtro de alumínio de $0,5 \mathrm{~mm}$ de espessura para minimizar os efeitos de beam hardering. Com uma resolução de imagem de $21 \mu \mathrm{m}$ e exposição de $300 \mathrm{~ms}$, as amostras foram fotografadas três vezes a cada $0.5^{\circ}$ de rotação até completarem $360^{\circ}$ de rotação da amostra.

O outro grupo de animais ( $n=11)$ em que foi verificado a contribuição das células-tronco humanas no período inicial da neoformação óssea foi anestesiado com uma injeção intraperitoneal contendo solução de $2 \%$ de xilazina e $5 \%$ de ketamina $(0,5 \mathrm{ml} / 100 \mathrm{~g}$ de massa corpórea). Em seguida, os animais foram escaneados utilizando o microtomógrafo computadorizado modelo Skyscan 1076 in vivo (Skyscan, Aartselaar, Belgium). Em cada animal foram utilizados os seguintes parâmetros: voltagem da fonte em $70 \mathrm{kv}$ e a corrente elétrica em $357 \mathrm{uA}$, e com filtro de $1 \mathrm{~mm}$ para minimizar os efeitos de beam hardering. Com uma resolução de imagem de 18 um e exposição de $300 \mathrm{~ms}$, as amostras foram fotografadas três vezes a cada $0.7^{\circ}$ de rotação até completarem $360^{\circ}$ de rotação da fonte. Após passarem pelo microtomógrafo os animais foram eutanaziados, de acordo com os tempos específicos de cada grupo: $07(n=3), 15(n=4)$ e 30 $(n=4)$ dias após a cirurgia e as calvárias foram coletadas para análise histológica.

Para reconstrução das imagens em 3D foi utilizado o programa NRecon v1.6.6.0 (Skyscan, Aartselaar, Belgium) configurado com as especificações a seguir: correção de beam hardering em $38 \%$ e correção dos artefatos em anéis em 7\%. Após a reconstrução das imagens foi utilizado o programa de análise CTan versão 1.13.21 - 64 bits (Skyscan, Aartselaar, Belgium). Primeiramente delimitamos a área da região de interesse para as análises, a qual compreendeu toda a região do defeito crítico e do biomaterial, e excluiu as bordas do osso 
parietal do rato. Para a eliminação dos pixels resultantes das fitas adesivas de fixação e os resultantes dos tecidos moles das amostras (pele, músculo, gordura, etc), foi realizada a adoção de um threshold de 35 a 255, o qual foi comum às amostras dos grupos ex vivo e in vivo. Em seguida, as amostras foram binarizadas e os dados foram gerados.

Das análises são obtidos diferentes parâmetros tais como: as alterações da razão do volume ósseo segmentado pelo volume total na região de interesse (BV/TV), a média do número de trabéculas (estruturas que delimitam os poros do biomaterial) por unidade de comprimento (TB.N), a média das espessuras das trabéculas (TB.Th), o grau de conectividade de trabéculas normalizado pelo volume de toda a região de interesse (Conn.D), a porcentagem de porosidade total (PO.Tot) e a porcentagem da distribuição da espessura das trabéculas.

Vale ressaltar que em virtude do biomaterial cerâmico utilizado neste estudo ser composto por HA/ $\beta$-TCP e ter composição semelhante ao osso, não é possível quantificar de forma isolada a neoformação óssea, sendo assim, os parâmetros obtidos das análises revelam o comportamento global da microarquitetura do enxerto nos períodos estudados. Entretanto, apesar destas dificuldades, estamos propondo uma forma alternativa para se fazer essa avaliação. Uma análise indireta pode ser feita a partir dos valores obtidos da distribuição das espessuras das trabéculas. Como a formação das ilhas ósseas ocorrem associadas às trabéculas do biomaterial, isto leva à variações na espessura destas trabéculas as quais podem ser quantificadas. A razão dos valores obtidos, entre os lados enxertados com células e os lados sem células, podem indicar indiretamente a neoformação óssea. 


\subsection{Análise Histológica com Coloração de Hematoxilina e Eosina}

Após a aquisição de imagens pelo micro-CT, as calotas cranianas foram fixadas em formol 4\% e descalcificadas em solução de EDTA 4\%. Em seguida, as calotas foram desidratadas, diafanizadas e embebidas em parafina. Os blocos de parafina contendo as amostras foram seccionados em $5 \mu \mathrm{m}$, transferidos para lâminas e estas, em seguida, foram coradas com hematoxilina e eosina (H.E), visualizadas e fotografadas no microscópio de luz Eclipse E-600 (Nikon, Dusseldorf, Alemanha).

\subsection{Análise Histológica por Fosfatase Ácida Tartarato- Resistente}

As lâminas contendo os cortes histológicos foram desparafenizadas com xilol e em seguida submetidas a marcação com fosfatase ácida resistente ao tartarato (TRAP) de acordo com o protocolo sugerido pelo fabricante (387A-1KT; Sigma-Aldrich). Analisamos três lâminas de cortes histológicos de cada animal, respeitando intervalos mínimos de $30 \mu \mathrm{m}$ entre os cortes. As células com coloração positiva e contendo mais de três núcleos foram consideradas osteoclastos. A quantidade de osteoclastos foi avaliada com uma objetiva de 40x e contando o número de células TRAP-positivas em duas regiões próximas às bordas do defeito crítico e quatros campos aleatórios na região medial do defeito.

\section{9}

\section{Imunohistoquímica - Detecção de Núcleo Humano}

Para a localização das células humanas inseridas no biomaterial enxertado nas calvárias dos ratos foram realizadas reações de imunohistoquímica, utilizando o anticorpo contra a lamina A/C humana 1:100 (MAB3211, Millipore).

Lâminas com $5 \mu \mathrm{m}$ de distância dos cortes corados com H.E foram desparafenizadas e hidratadas. A ativação do epítopo foi realizada através da 
incubação com Tris-Hcl $1 \mathrm{M}$ por 10 minutos à $90^{\circ} \mathrm{C}$ e o bloqueio da peroxidase endógena foi realizada usando solução de $3 \% \mathrm{H}_{2} \mathrm{O}_{2}(\mathrm{v} / \mathrm{v})$ por 5 minutos. Em seguida, foi utilizado o Kit Mouse On Mouse (M.O.M) (Vector, BMK-2202) de acordo com as recomendações do fabricante. $O$ kit preconiza a utilização do anticorpo secundário conjugado à peroxidase. Sendo assim, utilizamos diaminobenzidina (DAB), como agente colorimétrico para a deteç̧ão da expressão da lamina $A / C$ humana no tecido e o methy green foi utilizado para identificação dos núcleos celulares.

\subsection{Análise estatística}

Para a análise estatística dos resultados obtidos nos experimentos de diferenciação osteogênica in vitro e da fosfatase ácida tartarato-resistente, foi aplicado o teste paramétrico one way ANOVA seguido de pós-teste de comparações múltiplas de Bonferroni com 95\% de confiança. Os testes e os gráficos foram realizados no programa Graphpad InStat (Graphpad).

Os dados das análises de micro-CT foram transformados pelo método de Box-Cox e em seguida foram analisados pela análise de variâncias. Para identificar as diferenças entre as categorias de cada método foi utilizado o teste de Tukey de comparação múltiplas com $95 \%$ de confiança. Estas análises foram realizadas em colaboração com a professora $\mathrm{Dr}^{\mathrm{a}}$ Juliana Garcia Cespedes, do Departamento de Estatística da Universidade Federal de São Paulo. 


\section{Resultados}

\subsection{Caracterização Imunofenotípica de SHED e OOMDSC}

A caracterização das células-tronco mesenquimais obtidas da polpa de dente decíduo esfoliado $(n=4)$ e do músculo orbicular do lábio $(n=4)$ foi realizada por citometria de fluxo com sete marcadores de superfície celular. Observamos que as culturas celulares obtidas a partir destas duas fontes de tecidos apresentaram baixa marcação para os marcadores de superfície celular de linhagem hematopoiética CD45 (0,90\% - 2,84\%) e para o marcador endotelial CD31 (0,30\% - 2,08\%). Por outro lado, para os marcadores de adesão (CD29) e mesenquimais (CD73, CD90, CD105 e CD166) observamos altos níveis de marcações $(95,18 \%$ - 99,88\%) (Tabela 02).

Tabela 02: Porcentagem dos marcadores de superfície celular nas culturas celulares obtidas a partir de polpa de dentes decíduos esfoliados (SHED) e músculo orbicular do lábio (OOMDSC)

\begin{tabular}{ccc}
\hline \hline $\begin{array}{c}\text { MARCADORES } \\
\text { MOLECULARES }\end{array}$ & \multicolumn{2}{c}{ FONTES CELULARES } \\
\hline CD29 & $99,56 \%-99,84 \%$ & OOMDSC $(\mathbf{n}=4)$ \\
\hline CD31 & $0,52 \%-1,22 \%$ & $99 \%-99,88 \%$ \\
CD45 & $0,90 \%-2,84 \%$ & $0,30 \%-2,08 \%$ \\
CD73 & $97,08 \%-99,68 \%$ & $1,04 \%-2,52 \%$ \\
CD90 & $95,48 \%-99,52 \%$ & $98,74 \%-99,26 \%$ \\
CD105 & $95,24 \%-99,36 \%$ & $98,12 \%-99,88 \%$ \\
CD166 & $95,18 \%-99,56 \%$ & $95,16 \%-98,12 \%$ \\
\hline
\end{tabular}

SHED: células-tronco de polpa de dentes decíduos esfoliados ( $n=4)$. OOMDSC: células-tronco de músculo orbicular do lábio. CD29: marcador de superfície celular de adesão; CD31: marcador de superfície celular de linhagem endotelial; CD45: marcadores de superfície celular de linhagem hematopoiética; CD73, CD90, CD105 e CD166: marcadores de superfície celular mesenquimal. 


\subsection{Diferenciação Osteoblástica de SHED e OOMDSC in vitro}

A atividade da fosfatase alcalina (ALP) nas quatro amostras de SHED e nas quatro amostras de OOMDSC avaliadas neste trabalho foram quantificadas no 9ํ dia após o início da indução à diferenciação osteogênica (figura 03). A ALP fornece o fosfato necessário para a produção da matriz de cálcio e evidencia o início da diferenciação osteoblástica.

As células que foram tratadas com o meio de diferenciação osteogênica apresentaram ALP mais elevada do que os controles, que não receberam o meio de diferenciação, (Fig.03, A e B) sendo esta diferença significativa em todas as amostras $(p<0,05)$. Os dados apontam que ambas as culturas celulares têm capacidade de se diferenciar em osteoblastos.

$\mathrm{Na}$ figura $3 \mathrm{C}$, as médias das culturas celulares tratadas são comparadas com os seus respectivos controles. As SHED tratadas com o meio indutor apresentam aumento de 7,9 vezes $(p<0,0001)$ de ALP comparado ao controle. Enquanto as OOMDSC tratadas com o meio de diferenciação osteogênica apresentaram aumento de 3,3 vezes comparado ao seu controle $(p<0,001)$. A comparação entre os dois tipos de cultura celulares induzidos à diferenciação osteoblástica in vitro mostra que SHED tem 2,1 vezes mais ALP do que OOMDSC $(p<0,0001)$ neste período da diferenciação.

A avaliação da diferenciação osteoblástica após 14 e 21 dias de indução foi avaliada através da quantificação da mineralização da matriz extracelular produzida pelos osteoblastos diferenciados in vitro por meio da coloração por vermelho de alizarina (Fig.4, A e B). Após 14 dias do início da indução à diferenciação osteogênica (Fig.4 C), as SHED apresentaram 36 vezes mais coloração por vermelho de alizarina (VA) $(p<0,0001)$, enquanto as OOMDSC apresentaram 15,8 vezes mais $V A(p=0,0283)$ do que seus respectivos controles. A comparação da absorbância no comprimento de onda de $450 \mathrm{~nm}$ obtidas das soluções colorimétricas dos dois tipos de cultura celulares, após serem induzidas à diferenciação osteoblástica in vitro revelou que após 14 dias da indução, as SHED tem 2,3 vezes mais mineralização de matriz extracelular do que OOMDSC $(p<0,001)$. 
A

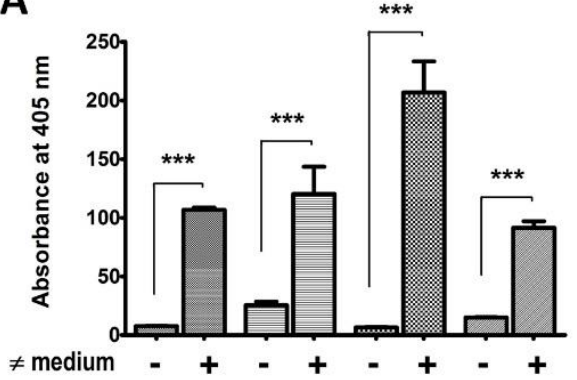

B

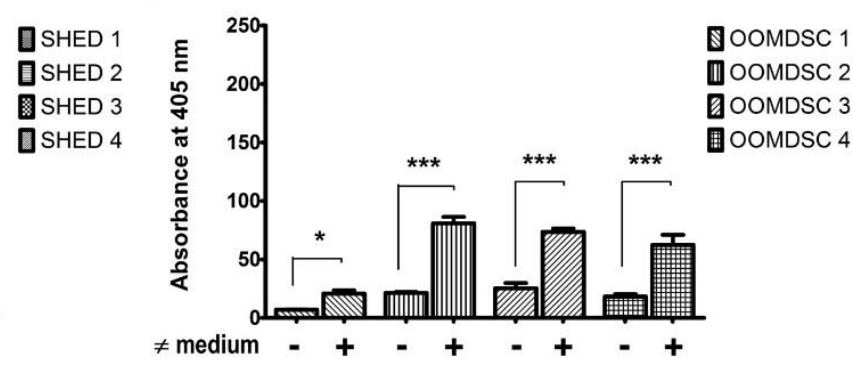

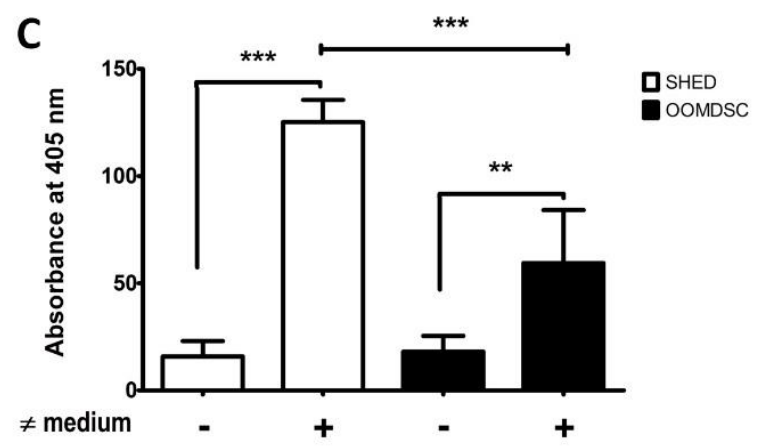

Figura 03. Quantificação da atividade da Fosfatase Alcalina em SHED ( $n=4)(A)$ e OOMDSC $(n=4)$ (B) no 9 dia de indução à diferenciação osteoblástica. Em A e B, as diferentes colunas representam as médias das triplicatas de cada amostra de SHED e OOMDSC, respectivamente. Em C observam-se as médias das amostras submetidas ao tratamento VS. o controle sem o tratamento, além da comparação das quantificações da atividade da fosfatase alcalina entre as SHED e as OOMDSC. O eixo das abscissas contém diferentes amostras; o eixo das coordenadas apresenta a absorbância (nm); ₹ médium: meio de diferenciação osteogênico; (-): controle sem o meio de diferenciação osteogênico; $(+)$ : células tratadas com o meio de diferenciação osteogênica; ** $p<0,001 ; * * * p<0,0001$.

No $21^{\circ}$ dia de cultivo com meio de diferenciação osteogênica (Fig.4 D), a coloração com vermelho de alizarina nas placas contendo SHED está 87 vezes aumentado ( $p<0,0001)$, e 69,6 vezes nas OOMDSC ( $p<0,0001)$ em relação ao controle. Contudo, a comparação da absorbância no comprimento de onda de 450nm obtidas das soluções colorimétricas de SHED e OOMDSC após serem tratadas com meio de diferenciação osteogênico por 21 dias, não foi significante. 
A

SHED 1

SHED 2

SHED 3

SHED 4

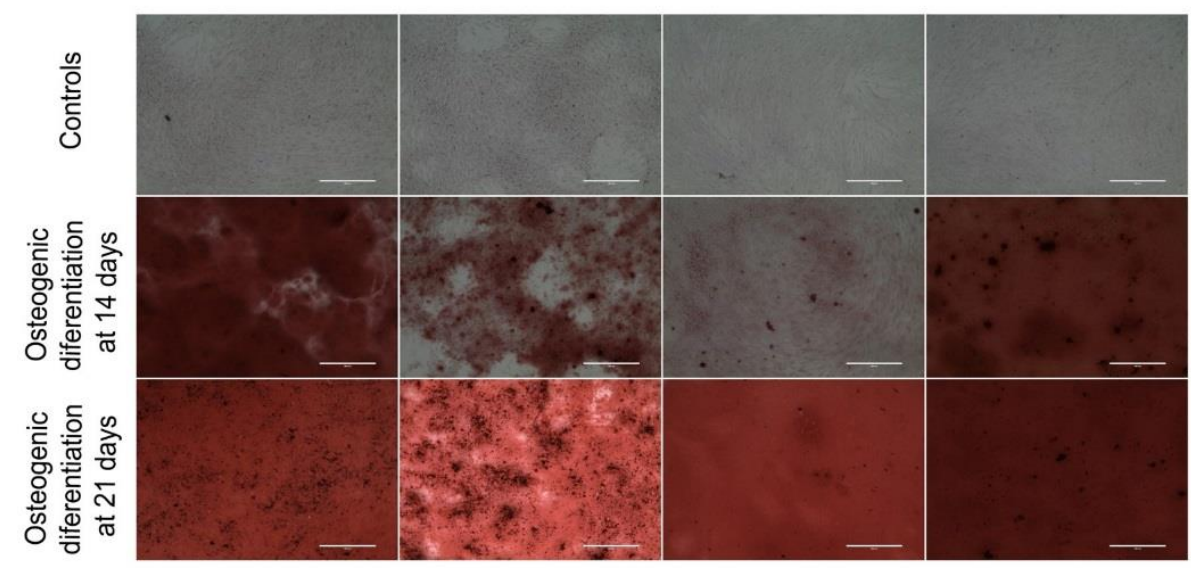

B

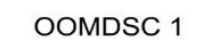

OOMDSC 2

OOMDSC 3

OOMDSC 4

을

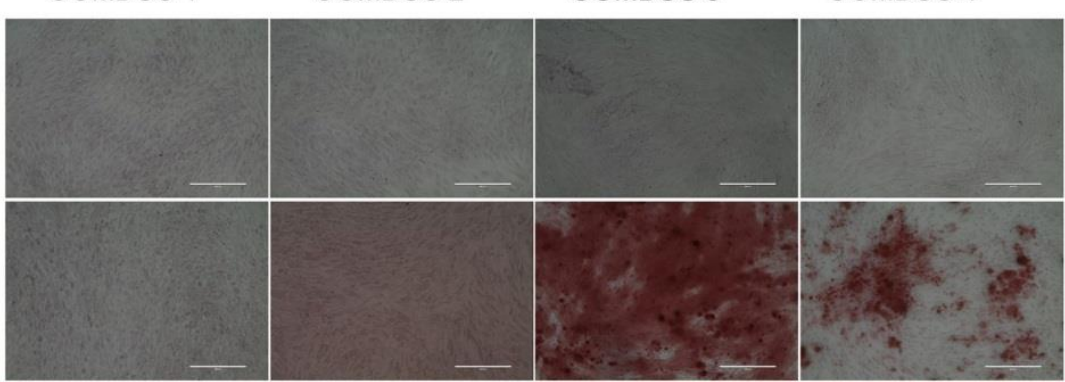

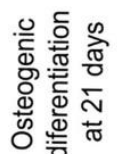

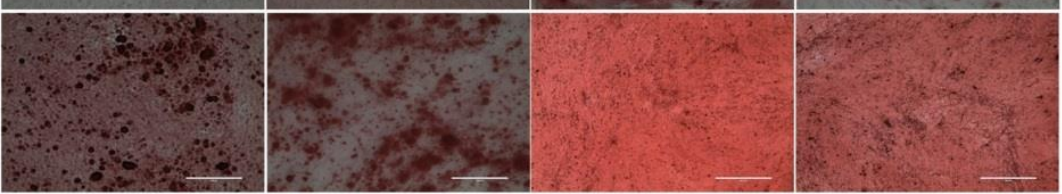

C

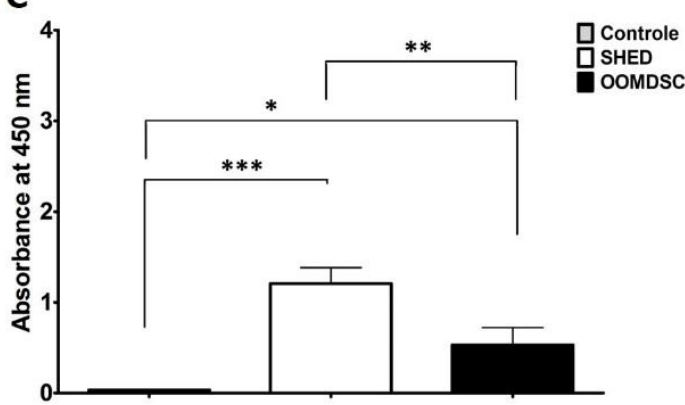

D

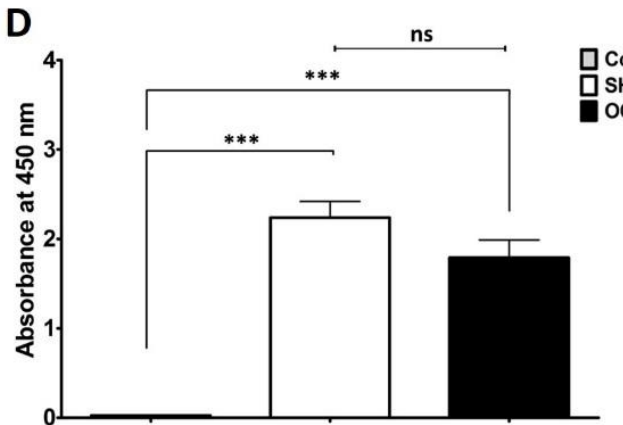

Figura 04. Marcação com vermelho de alizarina no 14 e 210 dia de indução à diferenciação osteoblástica das SHED, $n=4(A)$ e das $\operatorname{OOMDSC}(B), n=4$. Em A-B, cada coluna refere-se a uma amostra; na 1a linha é observado o controle de cada triplicata; na 2a e 3a linhas são observadas fotomicrografias representativas nos aumentos de $10 \mathrm{x}$ das triplicatas tratadas com o meio de indução. Nas figuras C e D, as diferentes colunas representam a média das triplicatas agrupadas das amostras de SHED e OOMDSC após 14 e 21 dias, respectivamente; o eixo das coordenadas apresenta a absorbância (nm); *p<0,05; ** $p<0,001 ;{ }^{* * *} p<0,0001$; ns: não houve diferença significativa. 


\subsection{Diferenciação Osteogênica de SHED e OOMDSC in vivo}

\subsubsection{Análise da Neoformação Óssea por Histologia}

Para verificarmos a contribuição das células enxertadas na neoformação óssea in vivo, utilizamos um total de nove ratos Wistar, o que correspondeu a 18 regiões a serem enxertadas: 06 foram transplantadas com SHED, 07 com OOMDSC e 05 controles. Após 50 dias, estas regiões foram analisadas por histologia.

A partir das análises histológicas das lâminas coradas com H.E observamos que o processo de neoformação óssea se dá a partir das extremidades, porção próxima ao tecido do hospedeiro em direção ao centro do defeito. Essa característica é observada, com pequenas variações, independentemente se foi usado SHED ou OOMDSC (Fig. 05, A - C). A porção superior do biomaterial é preenchida por células fibroblastóides imersas em tecido conjuntivo frouxo (Fig. 05, A' - C'). Na porção inferior do biomaterial, região onde foram associadas as células, observamos uma maior proporção de neoformação óssea (Fig. 05, A" - C"). A neoformação óssea ocorre no interior dos poros do biomaterial e dão origem as estruturas a que denominamos de ilhas ósseas (Fig. 05, b"); além disto, observamos que o número destas ilhas ósseas diminuem gradativamente em direção a porção superior do biomaterial. 
Controle
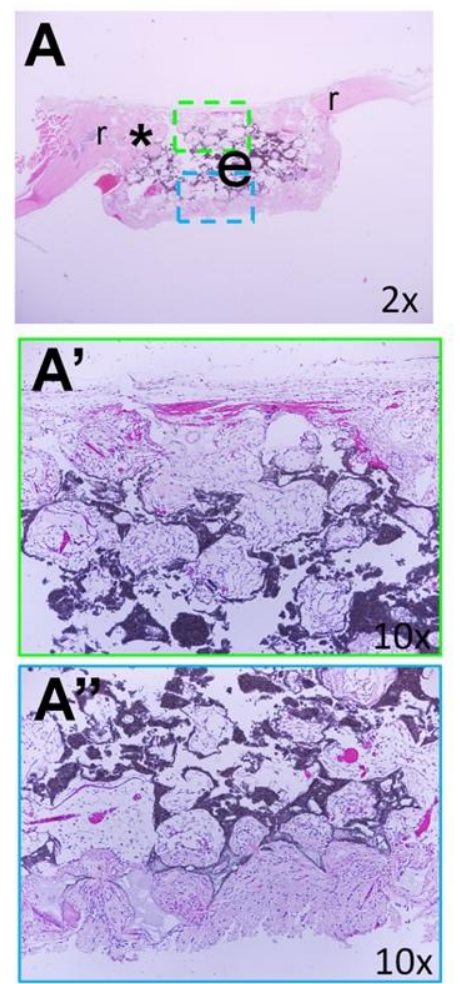
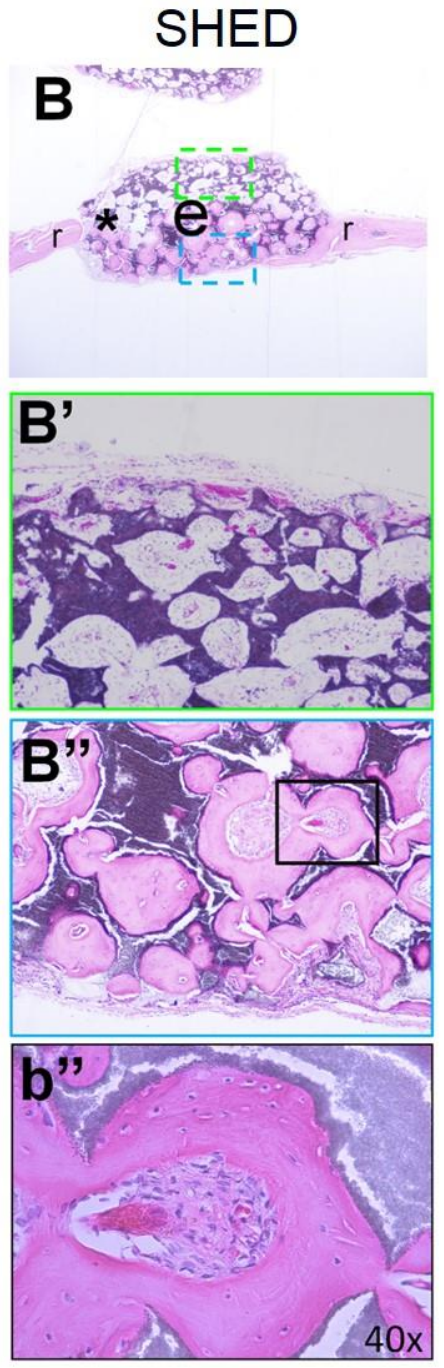

OOMDSC
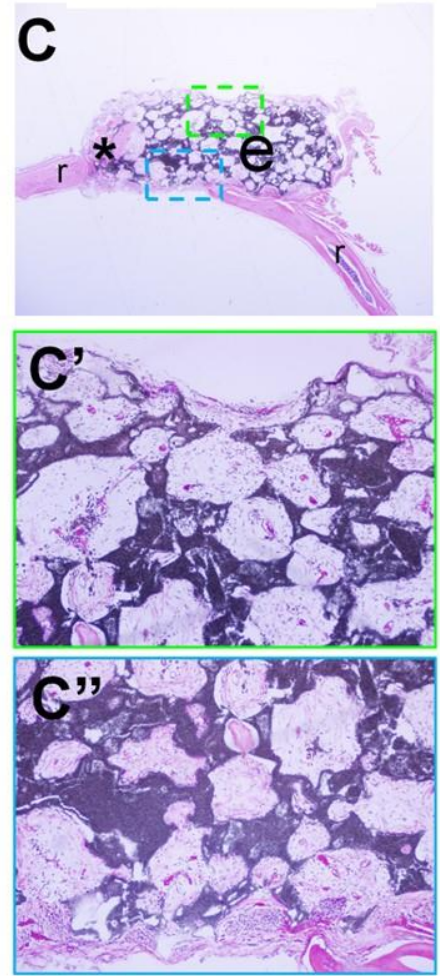

Figura 05. Fotomicrografia de luz de corte sagital de calvária de ratos dos grupos controle (A), SHED (B) e OOMDSC (C). A', B' e C' são detalhes em maior aumento das regiões delimitadas pela linha pontilhada em verde em A, B e C. Da mesma forma A", B" e C" são detalhes em maior aumento das regiões delimitadas pela linha pontilhada em azul em A, B e C. Uma ilha óssea formada na porção inferior do biomaterial é mostrada em detalhe ( $\left.b^{\prime \prime}\right)$. $O$ osso formado próximo ao biomaterial é organizado e de morfologia normal. e: biomaterial; r: osso parietal do receptor; asterisco $(*)$ : neoformação óssea periférica. 


\subsubsection{Quantificação da Neoformação Óssea por micro-CT}

O osso mineralizado neoformado nas calvárias dos ratos em que foram enxertadas as SHED $(n=06)$ e OOMDSC $(n=07)$ foi quantificado por meio da avaliação de imagens geradas por micro-CT ex vivo e comparado com controles $(n=05)$.

Após 50 dias de cirurgia a análise da fração de volume trabecular ósseo na região de interesse (BV/TV) mostrou que o volume ósseo era maior nos lados contendo SHED $(29,15 \pm 1,54 ; p=0,0443)$ e OOMDSC $(28,41 \pm 1,06 ; p=0,0413)$ quando comparado ao lado controle sem células $(25,35 \pm 0,59)$, Fig. 06 A e B.

A densidade de conexões (Conn.D) entre SHED, e OOMDSC foram equivalentes aos controles (Fig. $06 \mathrm{C}$ e D). A porosidade (PO.Tot) dos biomateriais enxertados com SHED $(58,29 \pm 2,97)$ foi $16,5 \%$ menor $(p=0,005)$ do que os lados sem células $(69,79 \pm 1,22)$ (Fig. $06 \mathrm{E}$ ) enquanto que nos lados contendo OOMDSC $(66 \pm 2,31)$ esta diferença não foi significativa $(p=0,2160)$ (Fig. 06 F).

Ao analisarmos a espessura média das trabéculas (TB.Th) que delimitam os poros do biomaterial observamos que o lado com SHED $(118,4 \mu \mathrm{m} \pm 0,69)$ tem as trabéculas mais espessas $(p=0,0154)$ do que o controle $(114,9 \mu \mathrm{m} \pm 0,96)$ (Fig. $06 \mathrm{G}$ ), enquanto que nos defeitos em que foram enxertadas as OOMDSC esta diferença na espessura não foi significativa $(p=0,3298)$ (Fig. $06 \mathrm{H})$.

O somatório das ilhas ósseas e as paredes dos poros do biomaterial, levam à variações na espessura das trabéculas as quais podem ser quantificadas. Ao analisar a distribuição das espessuras das trabéculas em 50 dias observamos que as trabéculas com tamanho médio de $0,186 \mathrm{~mm}$ nos lados contendo SHED são 1,27 vezes mais espessas $(p<0,0001)$ do que o lado controle (Fig. $06 \mathrm{I}$ ), enquanto nos animais que receberam OOMDSC, a diferença da espessura das trabéculas não foram significativas após 50 dias de cirurgia (Fig. $06 \mathrm{~J}$ ). 
A

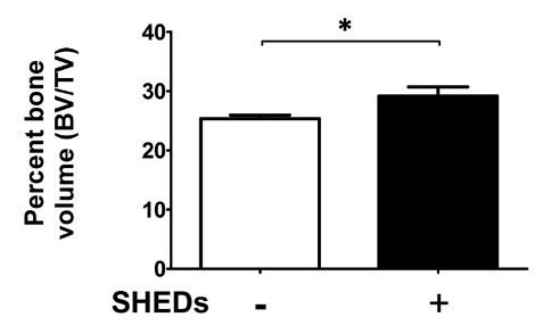

C

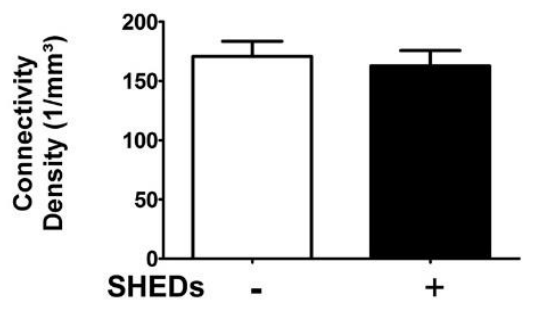

$\mathrm{E}$

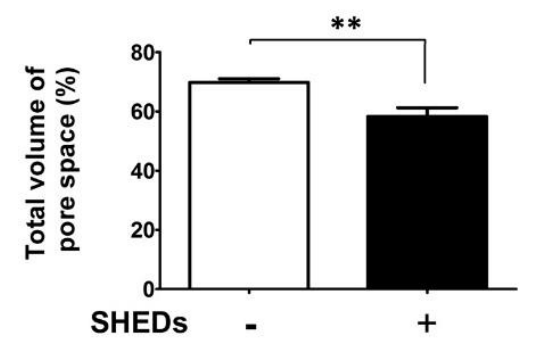

G

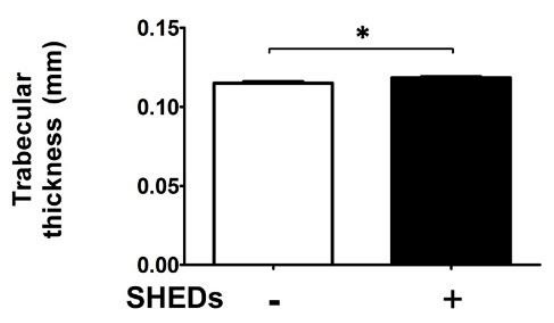

I

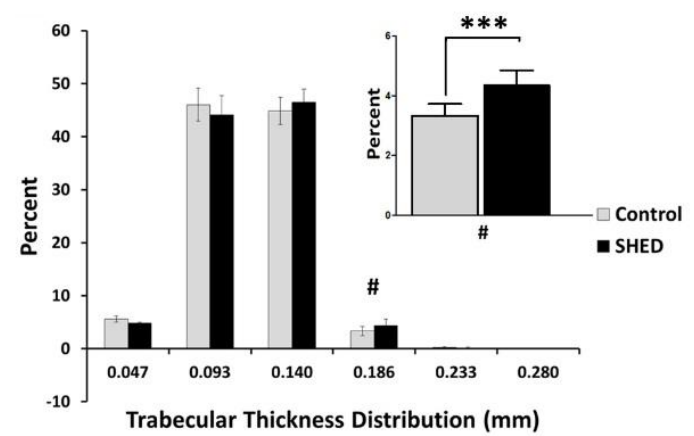

B

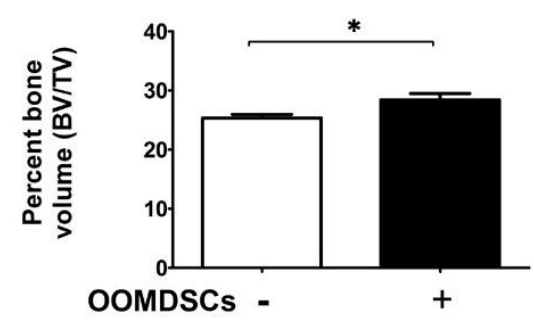

D

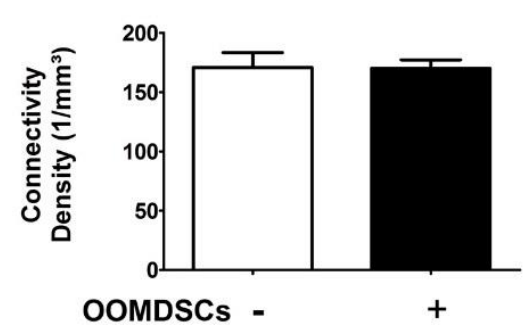

$\mathbf{F}$

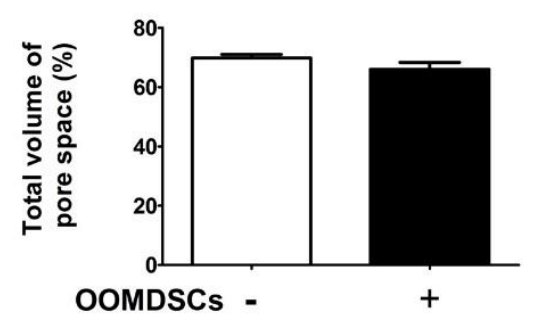

H

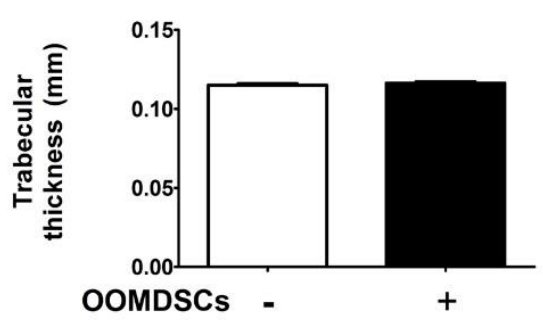

J

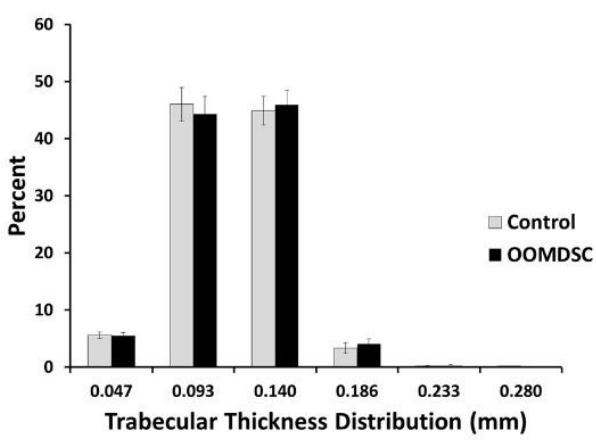

Figura 06. Quantificação do osso neoformado nos defeitos enxertados com SHED ( $n=06)$ e OOMDSC ( $n=07)$ após 50 dias de cirurgia. BV/TV: fração de volume trabecular ósseo na região de interesse (A e B); Conn.D: densidade de conexões (C e D); PO.Tot: porosidade (E e F); TB.Th: espessura média das trabéculas ( $\mathrm{G}$ e H); distribuição da espessura das trabéculas (I e J). (-): lado controle; (+): biomaterial + células (SHED ou OOMDSC). $\quad\left({ }^{*}\right)$ : $p<0,05 ;\left({ }^{* *}\right)$ : $p<0,001 ;\left({ }^{* * *}\right)$ : $p<0,0001$. Valores representadas pela média de cada grupo, seguido pelo desvio padrão da média.

Portanto as análises dos dados do BV/TV, TB.Th, PO.Tot e da distribuição da espessura das trabéculas do biomaterial indicam que as SHED podem estar 
associadas a um processo de neoformação óssea mais eficiente do que as OOMDSC.

\subsection{Avaliação in vivo da Contribuição das Células-Tronco Humanas no Osso Neoformado aos 50 dias Após à Cirurgia}

A fim de verificar se as neoformações ósseas em 50 dias seriam de origem humana, conduzimos reações de imunohistoquímica para detecção da expressão da lamina A/C humana nas secções de calotas cranianas contendo os enxertos.

O tecido conjuntivo localizado na porção superior dos cortes, conforme mostrado anteriormente (Fig. 05, A' - C'), apresentou células positivas para a marcação da lamina $A / C$ humana tanto em amostras contendo SHED quanto OOMDSC (Fig. 07, A - B'). Já nas ilhas ósseas neoformadas encontradas nas regiões do defeito crítico em que as SHED e OOMDSC foram enxertadas, não se observaram células positivas para lamina A/C humana (Fig. $07 \mathrm{C}$ ). A especificidade da marcação da lamina $A / C$ foi verificada por meio da utilização de tecidos humanos (controle positivos) usados concomitantemente aos testes, em cada reação (Fig. 07 F). Além disto, não foi verificada reatividade na marcação do tecido do hospedeiro, Fig. 07 D. 


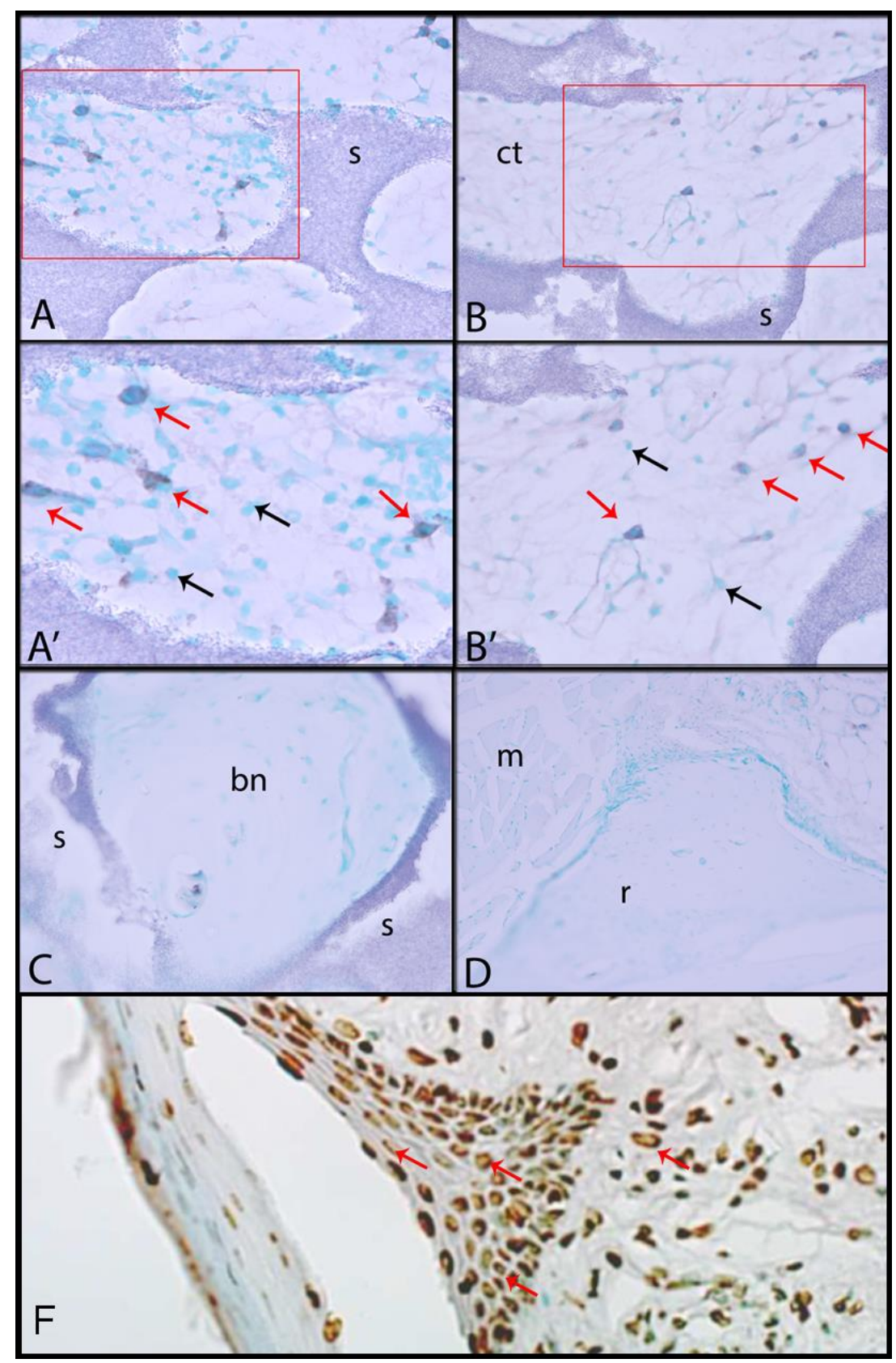

Figura 07. Localização das células humanas pela imunodetecção de lamina A/C humana. Tanto as células humanas de SHED (A) quanto as OOMDSC (B) associadas ao biomaterial (s) tiveram marcação positiva para a Lamina $A / C$ e estão localizadas no tecido conjuntivo (ct). ( $\left.A^{\prime}\right)$ detalhe da figura $A ;\left(B^{\prime}\right)$ detalhe da figura $B$; $(C)$ neoformação óssea $(b n)$ representativa de ambos os grupos; (D) Osso do hospedeiro ( $r$ ) e o músculo adjacente $(\mathrm{m})$ sem imunomarcacão para lamina A/C humana. Controle Negativo; (F) Tecido humano representativo, usado como controle positivo das reações. Setas vermelhas indicam marcação positiva para lamina A/C humana. Setas pretas indicam núcleos corados com methyl Green. Aumento de 40x. 


\section{5. $\quad$ Avaliação Tempo Dependente do Potencial Osteogênico das Células-Tronco in vivo}

Para avaliar a contribuição das células-tronco no início da neoformação óssea, nós associamos as SHED aos biomateriais, conforme descrito previamente. $\mathrm{O}$ grupo amostral contendo um total de 13 ratos foram analisados por histologia e micro-CT após quatro tempos pós-cirúrgicos: 24 horas $(n=2), 07$ $(n=3), 15(n=4)$ e $30(n=4)$ dias.

\subsubsection{Análise Histológica}

A análise morfológica dos cortes histológicos corados com H.E. mostram que em nenhum destes períodos foi observada a formação de ilhas de neoformação óssea dentro dos poros do biomaterial (Fig. 08 A - D).

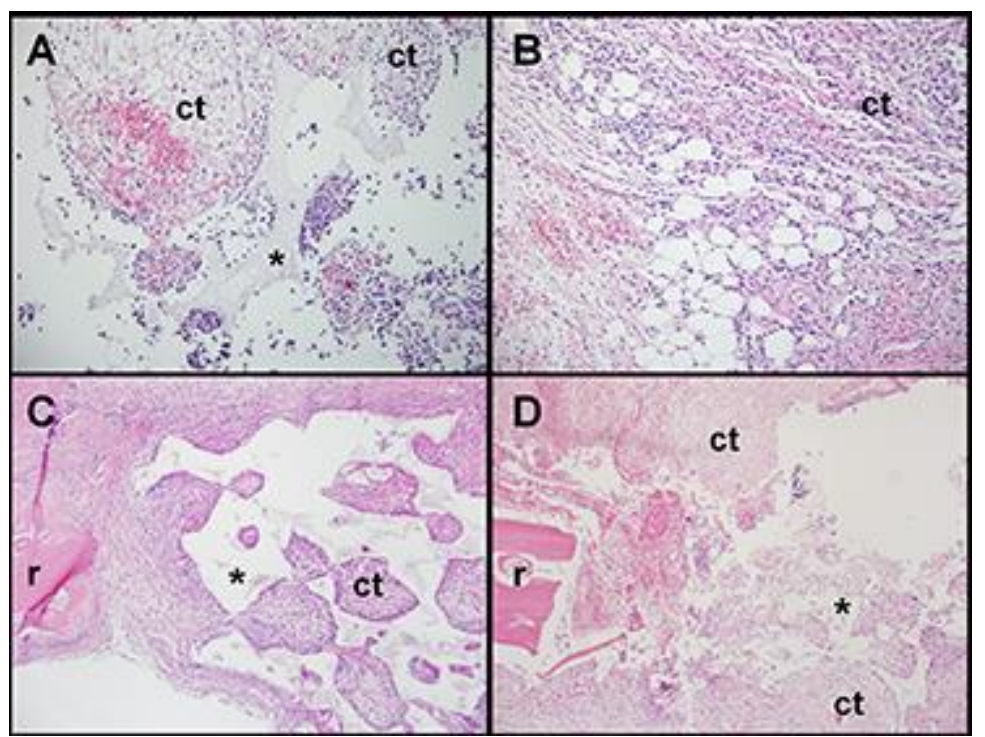

Figura 08. Cortes histológicos representativos corados com H.E. dos lados contendo SHED associadas à biomateriais em diferentes tempos pós-cirúrgicos: 24 horas $(n=2)(A) ; 07$ dias $(n=3)$ (B); 15 dias $(n=4)(C) ; 30$ dias $(n=4)$ (D). Asterisco (*): biomaterial; r: osso parietal do receptor; ct: tecido conjuntivo. 
A detecção por imunohistoquímica de lamina $A / C$ humana sugere a presença de SHED em todos os tempos analisados, distribuídas na porção inferior do biomaterial próxima a duramater e localizadas no tecido conjuntivo que preenche os poros (Fig. 09 A' - D', setas pretas).

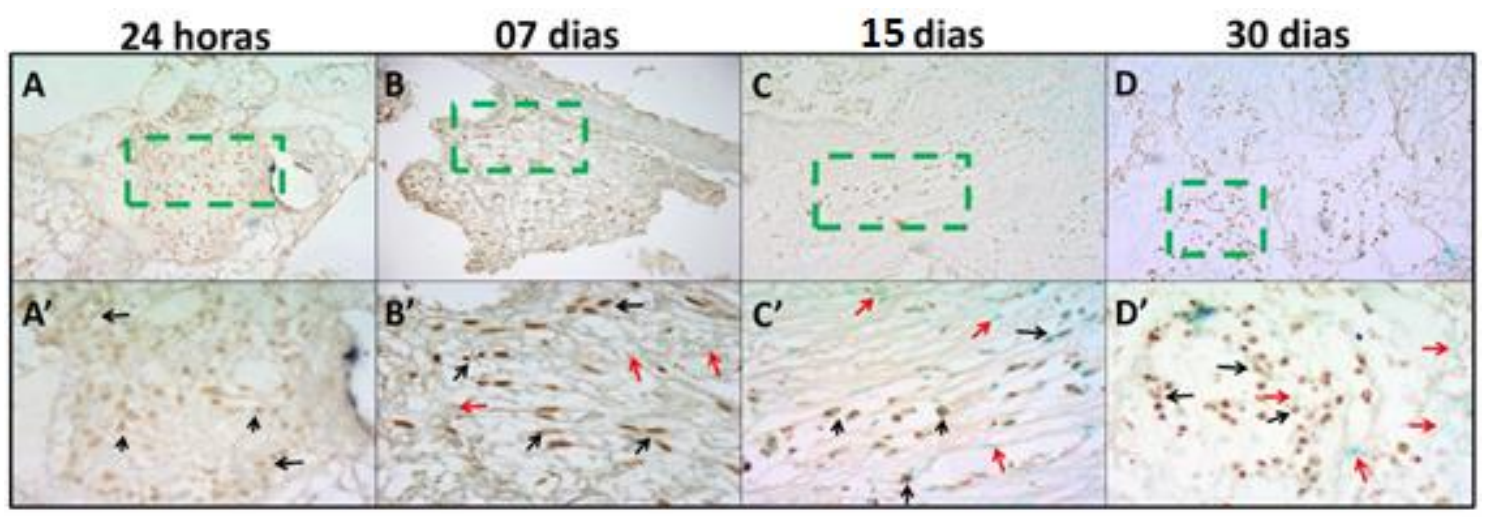

Figura 09. Localização das células humanas pela imunodetecção de lamina $A / C$ humana (reação de imunohistoquímica) em diferentes tempos pós-cirúrgicos: 24 horas $(n=2)(A) ; 07$ dias $(n=3)$ (B); 15 dias $(n=4)(C) ; 30$ dias $(n=4)$ (D). Células localizadas por toda a extensão do defeito em meio ao tecido conjuntivo. A'; $B^{\prime} ; C^{\prime} ; D^{\prime}$ são detalhes em aumento de $40 x$ das regiões $A, B, C, D$ respectivamente. Setas pretas indicam marcação positiva para lamina $A / C$ humana. Contra coloração realizada com methyl Green marcando os núcleos de verde (setas vermelhas).

\subsubsection{Análise por micro-CT}

Com exceção do grupo 24 horas, os demais animais $(n=11)$ foram analisados por micro-CT in vivo. Estas análises foram subdividas em dois grupos: $01^{\circ}$ refere-se à todas as leituras $(n=23$, tabela 03$)$ onde comparamos os lados com SHED vs. os lados sem células. $O 2^{\circ}$ grupo é composto pelos mesmos quatro animais, os quais foram acompanhados desde o $7^{\circ}$ dia até o $30^{\circ}$ dia com micro-CT in vivo. A avaliação da dinâmica na região enxertada foi realizada nos lados controles (tabelas 04) e nos lados contendo SHED (tabela 05) separadamente. 


\subsubsection{Análises do Grupo 01}

A análise da fração de volume trabecular ósseo na região de interesse (BV/TV) mostrou que em 07 dias após a cirurgia, o lado controle $(n=11 ; 36,77 \pm$ $0,83)$ é maior ( $p=0,0190)$ em relação ao lado com SHED $(n=11 ; 34,08 \pm 0,95)$. Em 15 dias os lados com células $(n=8 ; 38,24 \pm 1,425)$ contudo foram maiores $(p=0,0135)$ que os dos controles $(n=8 ; 34,90 \pm 1,02)$. Já em 30 dias após a cirurgia não houve diferença $(p=0,2062)$ significativa de BV/TV entre os lados contendo células ( $n=4 ; 36,73 \pm 2,414)$ e os lados controles sem células $(n=4$; $32,69 \pm 1,514)$.

Ao analisarmos a espessura média das trabéculas (TB.Th) que delimitam os poros do biomaterial verificamos que não houve diferença significativa, tanto em 07 e 15 dias. Entretanto, no $30^{\circ}$ dia ocorre um aumento $(p=0,0009)$ nos lados contendo SHED $(0,09888 \pm 0,00031)$ quando comparado com os lados controles $(0,09474 \pm 0,0006122)$. Na análise da distribuição das espessuras das trabéculas no $30^{\circ}$ dia (Fig. 10) é observado um aumento de 1,65 vezes $(p<0,0001)$ na porcentagem de trabéculas com tamanho médio de $0,139 \mathrm{~mm}$ nos lados enxertados com SHED ( $n=4 ; 12,84 \% \pm 0,67)$, em relação ao lado controle $(n=4 ; 7,75 \% \pm 1,29)$. Neste mesmo tempo pós-cirúrgico a porcentagem de trabéculas com tamanho médio de $0,174 \mathrm{~mm}$ foi 2,65 vezes maior $(p<0,0001)$ nos lados enxertados com biomateriais associados às SHED, $(n=4 ; 0,99 \% \pm 0,10)$ quando comparado ao lado controle $(n=4 ; 0,37 \% \pm 0,39)$. 


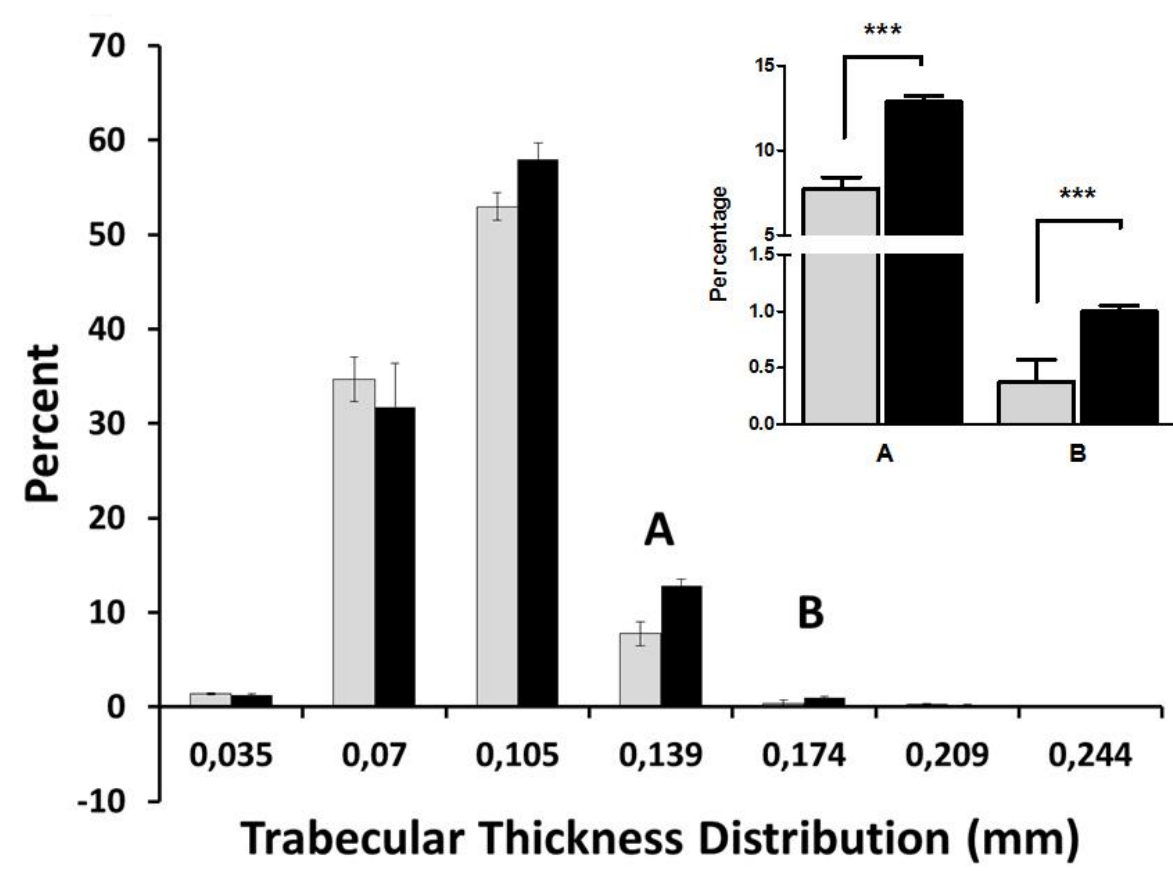

Figura 10. Gráficos das distribuições das espessuras das trabéculas após 30 dias de cirurgia. Em detalhe trabéculas com tamanho médio de 0,139mm (A) e 0,174mm (B). $\left.{ }^{* * *}\right): p<0,0001$.

Ao quantificarmos o número médio de trabéculas (TB.N) constatamos que em 07 dias o lado controle tem mais trabéculas $(n=11 ; 3,827 \pm 0,1467)$ comparado ao lado com células ( $n=11 ; 3,524 \pm 0,1232), p=0,0458$. O mesmo foi visto em 15 dias, o lado controle apresenta mais trabéculas $(n=8 ; 3,968 \pm$ $0,1855)$ do que o lado com SHED ( $n=8 ; 3,618 \pm 0,1316), p=0,0223$. No entanto, em 30 dias não há diferença significativa $(p=0,112)$ entre o TB.N de controles $(n=4 ; 3,879 \pm 0,2636)$ e lados com células $(n=4 ; 3,306 \pm 0,1570)$.

A densidade de conexões (Conn.D) entre os poros dos biomateriais foram equivalentes tanto entre controles e os lados enxertados com SHED em 07 e 15 dias de cirurgia. Contudo em 30 dias, o lado contendo células $(n=4 ; 198,4 \pm$ $9,063)$ apresentou menos Conn.D ( $p=0,0201)$ quando comparado com o lado controle sem células $(n=4 ; 292,8 \pm 28,71)$.

Em seguida ao quantificarmos a porosidade total (PO.Tot) nos biomateriais enxertados verificamos que não houve diferença significativa entre ambos os lados nos períodos analisados. 
Portanto, a diminuição da Conn.D e TB.N e concomitantemente o aumento de BV/TV e TB.Th sugerem modificações na microarquitetura do enxerto nos lados contendo biomateriais associados à SHED. De fato, ao analisar a distribuição do tamanho das trabéculas, é observado um aumento na porcentagem de trabéculas mais espessas nos lados enxertados com SHED.

\subsubsection{Análises do Grupo 02}

A análise in vivo dos quatro animais enxertados apenas com biomateriais (sem células), revelam nenhuma modificação estrutural na microarquitetura do biomaterial entre 07 e 30 dias após as cirurgias. A única exceção é em relação ao BV/TV, o qual ocorre uma diminuição $(p=0,0046)$ em 30 dias $(32,69 \pm 1,51)$ quando comparado com as medidas realizadas no $15^{\circ}$ dia $(41,08 \pm 1,17)$.

Quando avaliado o lado contendo biomaterial associado à SHED nestes mesmos períodos e animais, outros parâmetros demonstram-se alterados: ocorre um aumento na TB.Th $(p=0,0024)$ entre 15 dias $(0,09524 \pm 0,00065)$ e 30 dias $(0,09888 \pm 0,00031)$. Enquanto a TB.N diminui $(p=0,0083)$ entre 15 dias $(3,925 \pm 0,03)$ e 30 dias $(3,306 \pm 0,15)$. O mesmo é observado em relação à Conn.D, a qual encontra-se diminuída $(p=0,0005)$ neste mesmo período.

Em geral, a microarquitetura do biomaterial permanece constante no lado controle, com exceção da diminuição do BV/TV em 30 dias a qual pode estar associada a um processo de absorção do biomaterial. Por outro lado, a análise da dinâmica na região enxertada com células sugere um início de formação óssea. 
Tabela 3: Avaliação da microarquitetura óssea trabecular por micro-CT

\begin{tabular}{|c|c|c|c|c|c|c|c|}
\hline \multirow{2}{*}{$\begin{array}{c}\text { Medição } \\
\text { Defeito critico } \\
\text { calvarial }\end{array}$} & \multirow[t]{2}{*}{ Unidade } & \multicolumn{2}{|c|}{$\begin{array}{l}07 \text { dias } \\
(\mathrm{N}=11)\end{array}$} & \multicolumn{2}{|c|}{$\begin{array}{c}15 \text { dias } \\
(\mathrm{N}=8)\end{array}$} & \multicolumn{2}{|c|}{$\begin{array}{c}30 \text { dias } \\
(\mathrm{N}=4)\end{array}$} \\
\hline & & $(-)$ & $(+)$ & $(-)$ & $(+)$ & $(-)$ & $(+)$ \\
\hline BV/TV & $\%$ & $36,77 \pm 0,83$ & $\begin{array}{c}34,08 \pm 0,95 \\
\star\end{array}$ & $34,90 \pm 1,02$ & $\begin{array}{c}38,24 \pm 1,42 \\
\star\end{array}$ & $32,69 \pm 1,51$ & $36,73 \pm 2,41$ \\
\hline TB.Th & $\mathrm{mm}$ & $\begin{array}{c}0,09363 \pm \\
0,00059\end{array}$ & $\begin{array}{c}0,09478 \pm \\
0,00084\end{array}$ & $\begin{array}{l}0,0967 \pm \\
0,00124\end{array}$ & $\begin{array}{l}0,097 \pm \\
0,0010\end{array}$ & $\begin{array}{l}0,0947 \pm \\
0,00061\end{array}$ & $\begin{array}{c}0,0988 \pm \\
0,00031 \\
\star \star \star\end{array}$ \\
\hline TB.N & $1 / \mathrm{mm}$ & $3,827 \pm 0,1467$ & $\begin{array}{c}3,524 \pm 0,1232 \\
\star\end{array}$ & $3,968 \pm 0,1855$ & $\begin{array}{c}3,618 \pm 0,1316 \\
\star\end{array}$ & $3,879 \pm 0,2636$ & $3,306 \pm 0,1570$ \\
\hline Conn.D & $1 / \mathrm{mm}^{3}$ & $308,5 \pm 19,38$ & $308,5 \pm 19,38$ & $300,1 \pm 32,32$ & $261,3 \pm 18,79$ & $292,8 \pm 28,71$ & $\begin{array}{c}198,4 \pm 9,063 \\
\star\end{array}$ \\
\hline PO.Tot & $\%$ & $64,23 \pm 1,24$ & $66,66 \pm 1,04$ & $63,01 \pm 1,16$ & $65,10 \pm 1,02$ & $63,27 \pm 2,41$ & $62,56 \pm 1,39$ \\
\hline
\end{tabular}

Quantificação das microestruturas dos biomateriais enxertados contendo ou não células em 07, 15 e 30 dias. BV/TV: fração de volume trabecular ósseo na região de interesse; TB.Th: espessura média das trabéculas; TB.N: número de trabéculas; Conn.D: densidade de conexões; PO.Tot: porosidade. (-): lado controle; $(+)$ : biomaterial + células. Valores representadas pela média de cada grupo, seguido pelo desvio padrão da média. $\left({ }^{*}\right)$ apresentam $p<0,05 ;\left({ }^{* * *}\right)$ apresentam $\mathrm{p}=0,0009$. 
Tabela 04: Avaliação por micro-CT in vivo dos lados controles nos quatro animais selecionados para o grupo 02

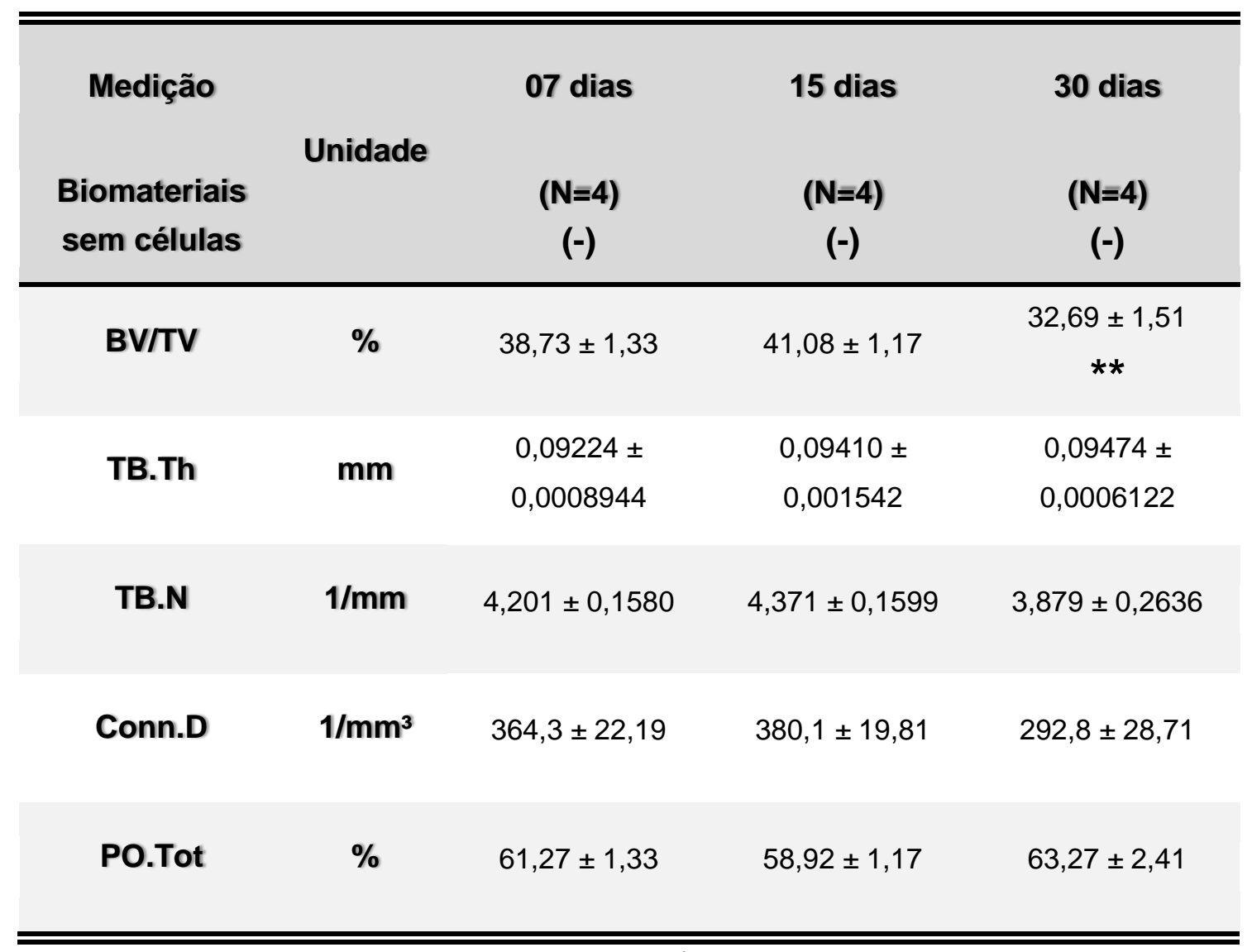

$\overline{\text { Dados gerados por micro-CT in vivo a partir das análises na região enxertada contendo apenas }}$ biomateriais (controles). BV/TV: fração de volume trabecular ósseo na região de interesse; TB.Th: espessura média das trabéculas; TB.N: número de trabéculas; Conn.D: densidade de conexões; PO.Tot: porosidade. (-): lado controle; (+): biomaterial + células. Valores representadas pela média de cada grupo, seguido pelo desvio padrão da média. $\left({ }^{* *}\right)$ : $p<0,01$. 
Tabela 05: Avaliação por micro-CT in vivo dos lados contendo SHED nos quatro animais selecionados para o grupo 02

\begin{tabular}{|c|c|c|c|c|}
\hline $\begin{array}{c}\text { Medição } \\
\text { Biomateriais } \\
\text { com SHED }\end{array}$ & Unidade & $\begin{array}{l}07 \text { dias } \\
(\mathrm{N}=4) \\
(+)\end{array}$ & $\begin{array}{c}15 \text { dias } \\
(\mathrm{N}=4) \\
(+)\end{array}$ & $\begin{array}{l}30 \text { dias } \\
(\mathrm{N}=4) \\
(+)\end{array}$ \\
\hline BV/TV & $\%$ & $35,01 \pm 0,99$ & $37,38 \pm 0,31$ & $36,73 \pm 2,41$ \\
\hline TB.Th & Mm & $\begin{array}{l}0,09544 \pm \\
0,0006831\end{array}$ & $\begin{array}{l}0,09524 \pm \\
0,0006566\end{array}$ & $\begin{array}{c}0,09888 \pm \\
0,0003161 \\
\star \star\end{array}$ \\
\hline TB.N & $1 / \mathrm{mm}$ & $3,669 \pm 0,1031$ & $3,925 \pm 0,03169$ & $\begin{array}{c}3,306 \pm 0,1570 \\
\star \star\end{array}$ \\
\hline Conn.D & $1 / \mathrm{mm}^{3}$ & $276,0 \pm 13,84$ & $297,9 \pm 11,23$ & $\begin{array}{c}198,4 \pm 9,063 \\
\star \star \star\end{array}$ \\
\hline PO.Tot & $\%$ & $64,99 \pm 0,99$ & $62,62 \pm 0,31$ & $62,56 \pm 1,39$ \\
\hline
\end{tabular}

$\overline{\text { Dados gerados por micro-CT in vivo a partir das análises na região enxertada contendo apenas }}$ biomateriais (controles). BV/TV: fração de volume trabecular ósseo na região de interesse; TB.Th: espessura média das trabéculas; TB.N: número de trabéculas; Conn.D: densidade de conexões; PO.Tot: porosidade. (-): lado controle; (+): biomaterial + células. Valores representadas pela média de cada grupo, seguido pelo desvio padrão da média. $\left.{ }^{* *}\right)$ : $p<0,01$; $(* * *): p<0,001$ 


\subsubsection{Análise do Número de Osteoclastos no Processo de Neoformação Óssea}

Após coloração com TRAP, os osteoclastos foram identificados ao longo de todo o biomaterial (citoplasma avermelhado e multinuclear) em todos os períodos analisados (Fig.11 A). Além disto, são observadas em detalhes as lacunas de Howship, face do osteoclasto responsável pela reabsorção (Fig. 11 $A^{\prime}$, setas verdes).

Quando comparada a contagem dos osteoclastos no lado controle dos três períodos estudados, foi observado que o número de osteoclastos varia de acordo com o tempo (Fig.11 B). Entre 07 e 15 dias a quantidade de osteoclastos aumenta ( $p=0,0029$ ) e além disto, foi maior do que qualquer outro dia. Entre os dias 15 e 30 a quantidade de osteoclastos diminui $(p=0,0002)$.

Quando comparada a contagem dos osteoclastos no lado contendo SHED dos três períodos estudados, apesar de ter havido um aumento destas células com 15 dias, tanto em relação a 7 dias como em 30 dias, estas diferenças não foram estatisticamente diferentes (Fig.11 C).

A análise comparativa da quantidade de osteoclastos entre os lados controles e os lados contendo SHED associadas à biomateriais nos dias 7, $15 \mathrm{e}$ 30 , não revelou nenhuma diferença entre a quantidade de osteoclastos entre dois grupos (Fig. $11 \mathrm{D})$.

Portanto, estes resultados sugerem que a perda de biomaterial seja devido, ao menos em parte, pela açãodos osteoclastos medidos. 
A

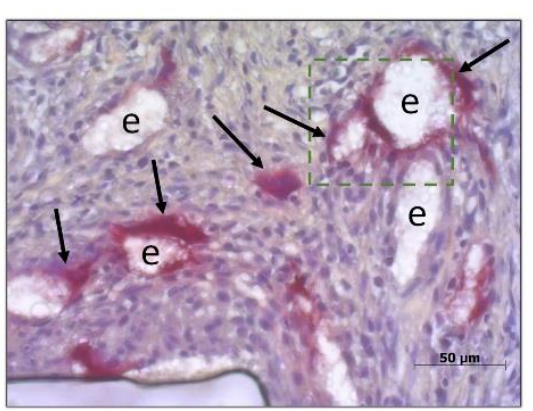

B

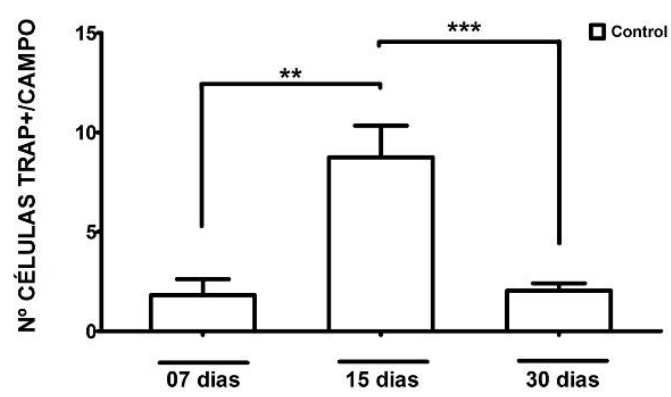

$A^{\prime}$

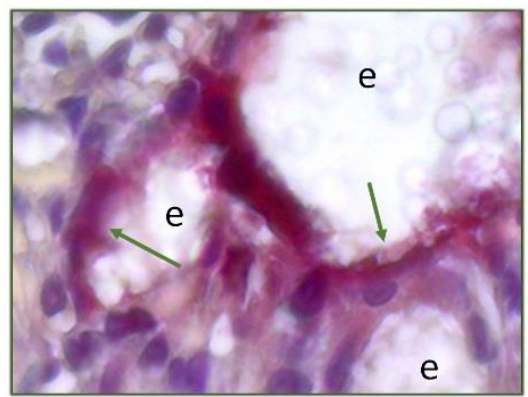

C

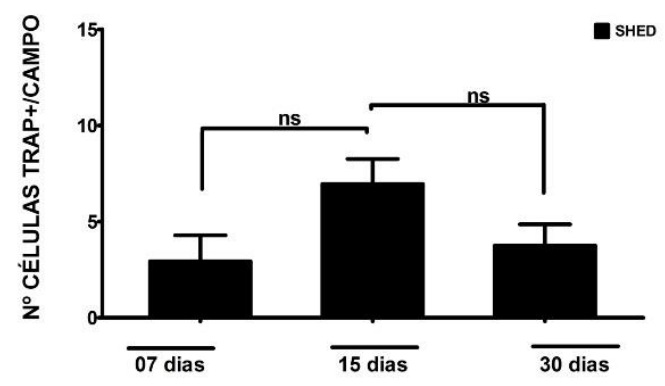

D

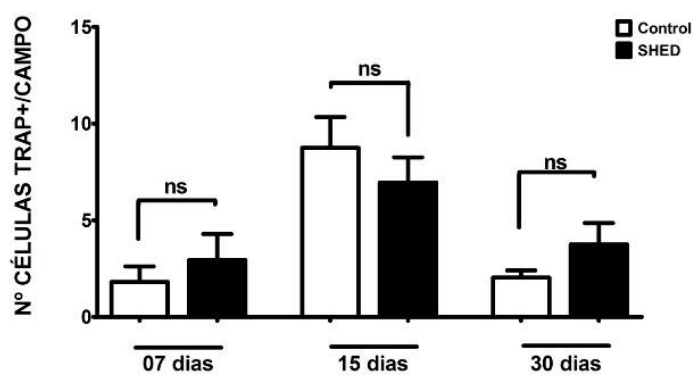

Figura 11. Identificação e contagem dos osteoclastos após a marcação com TRAP. Fotomicrografia representativa de células marcadas positivamente $(A)$, aumento de 40x; $\left(A^{\prime}\right)$ Detalhe da figura $A$, setas verdes apontam as lacunas de Howship; Comparação da contagem dos osteoclastos apenas nos lados controles (B) e nos lados enxertados com SHED (C); Comparação da quantificação do número de osteoclastos entre os lados enxertados com SHED e os lados controles em diferentes tempos (D). Setas pretas indicam marcação positiva para TRAP. "e": biomaterial. Contra coloração realizada com hematoxilina Gill no3 marcando os núcleos de roxo; e: biomaterial; $\left({ }^{* *}\right) p<0,01 ;\left({ }^{* * *}\right) p<0,001$; ns: não houve diferença significativa. 


\section{Discussão}

No presente trabalho comparamos a diferenciação osteoblástica in vitro e in vivo de duas fontes de células-tronco, SHED e OOMDSC, e se estas célulastronco contribuem para a neoformação óssea in vivo. Ambas facilmente obtidas e com potencial de uso na engenharia de tecidos ósseos (BUENO et al., 2009; MAO et al., 2006; SEO et al., 2008).

As SHED e OOMDSC foram adequadamente caracterizadas de acordo com os critérios imunofenotípicos estabelecidos pela Sociedade Internacional de Terapia Celular para CTMs humanas (DOMINICl et al., 2006), ou seja, apresentaram baixos níveis de expressão de marcadores de células hematopoiéticas e endoteliais, e elevada expressão dos marcadores de células mesenquimais (CD73, CD90, CD105 e CD166). Juntos, estes resultados confirmam as características de CTMs destas culturas celulares primárias e compartilham o perfil imunofenotípico descrito por outros autores (BUENO et al., 2009; KERKIS \& CAPLAN, 2012; RODRíGUEZ-LOZANO et al., 2012).

A capacidade de diferenciação de SHED e OOMDSC em osteoblastos é conhecida (BUENO et al., 2009; MIURA et al., 2003; NOURBAKHSH et al., 2011). Entretanto a análise quantitativa comparativa da potencialidade osteoblastogênica destas duas fontes de CTMs ainda não havia sido avaliada.

Os nossos resultados mostram que as OOMDSC apresentam uma menor indução da atividade de ALP, no 9 o dia em cultura, quando comparado com as SHED, o que indica que OOMDSC se diferenciam em osteoblastos mais lentamente do que as SHED, uma vez que níveis elevados da atividade de ALP indicam uma diferenciação osteoblástica mais rápida (HU et al., 2009; YIN et al., 2013).

Nosso resultado mostra que quando diferenciadas em osteoblastos, as OOMDSC em 14 dias são menos coradas por vermelho de alizarina do que as SHED, enquanto que em 21 dias esta diferença não é observada quando comparamos OOMDSC e SHED. Isto sugere que o processo de maturação da 
diferenciação osteoblástica das OOMDSC é também mais lenta do que nas SHED, entretanto o resultado no final da diferenciação in vitro é semelhante entre estas células-tronco mesenquimais provenientes de duas fontes diferentes.

Portanto, a partir destes resultados, verificamos que apesar das OOMDSC se diferenciarem mais lentamente em osteoblastos, ao final deste processo, elas apresentam um potencial osteoblástico in vitro semelhante ao das SHED. Tendo em vista este resultado, julgamos importante verificar se OOMDSC também contribuem de forma semelhante na neoformação óssea in vivo.

No estudo de diferenciação osteogênica in vivo, observamos a presença de neoformação óssea tanto nos lados enxertados com OOMDSC e SHED, entretanto, existem diferenças nítidas entre estes dois grupos. Os lados contendo OOMDSC apresentam mais neoformação óssea quando comparados com os lados controles, enquanto que nos lados enxertados com SHED a neoformação óssea, foi superior às OOMDSC e aos controles (SHED> OOMDSC> controles).

Além disto, observamos um gradiente de neoformação óssea após 50 dias de cirurgia, o que pode ser explicado por dois fatores: o método de associação das células e o tamanho dos poros do biomaterial ao qual as células foram associadas. Primeiramente, pode ter ocorrido uma distribuição celular desigual no biomaterial, resultante da aplicação das células em apenas uma de suas faces, a qual apresentaria uma maior neoformação óssea. De fato, a quantidade de células associadas ao biomaterial é importante, como observado por QUARTO e colaboradores (2001) que, ao estudarem o reparo de grandes defeitos ósseos, demonstraram que a regeneração era dependente da quantidade de células-tronco presentes. Além disso, ALY e colaboradores (2012) observaram que as células podem bloquear os poros e reduzir a conectividade do biomaterial, caso os poros tenham diâmetro inferior a $500 \mu \mathrm{m}$. É possível que isto tenha ocorrido ao biomaterial utilizado por nós, já que o tamanho dos poros, apesar de variar entre 100 e $800 \mu \mathrm{m}$, tinha $300 \mu \mathrm{m}$ em média. Uma forma para contornar estes problemas, poderia ser a utilização de biorreatores, os quais possibilitam uma melhor distribuição das células por todo o biomaterial quando 
comparado com o método de sobreposição das células sobre o biomaterial (ALVAREZ-BARRETO et al., 2007; BURG et al., 2000; RAUH et al., 2011).

Até recentemente, as técnicas histológicas quantitativas eram consideradas o padrão para a avaliação da arquitetura trabecular e cortical do osso, porém, atualmente a técnica de micro-CT é o padrão ouro para avaliar a morfologia e a microarquitetura óssea de pequenos modelos animais (BOUXSEIN et al., 2010). Entretanto esta técnica apresenta algumas limitações. A avaliação das nossas amostras por micro-CT foi dificultada por conta da composição química do biomaterial utilizado por nós, o qual é composto por HA/ $\beta$-TCP e esta composição, é semelhante ao do osso. Sendo assim, a distinção entre a neoformação óssea e o biomaterial torna-se imprecisa e, consequentemente, realizar uma quantificação isolada da neoformação óssea fica inviável. De fato, a dificuldade em analisar estes tipos de biomateriais já foi discutida por outros pesquisadores e, em razão disto, a maioria dos artigos não apresenta quantificação do osso neoformado no interior destes biomateriais. Estes estudos restringem-se a mostrar a reconstrução 3D das amostras, seguido por uma análise qualitativa (NIEMEYER et al., 2010; ROOHANI-ESFAHANI et al., 2012). A dificuldade em separar o biomaterial do osso neoformado foi observada por YE e colaboradores (2012), ao enxertarem no compartimento subcutâneo de camundongos, biomateriais cerâmicos de $\beta$-TCP associados à BMSCs. Contudo, neste estudo, as análises de volume ósseo e densidade mineral compreendiam os biomateriais. Apesar disto, eles observaram que a neoformação óssea se dava no interior dos poros, se estendia aos poros adjacentes através da interconectividade do biomaterial e após 8 semanas, todos os poros estavam completamente preenchidos.

Diante destas dificuldades, estamos propondo uma nova forma de fazer essa avaliação. Assim ao invés de medir a neoformação óssea a partir dos parâmetros de volume ósseo (BV/TV), avaliamos o processo de neoformação óssea indiretamente, através da análise da espessura das estruturas que delimitam os poros dos biomateriais, aqui chamadas de trabéculas. $O$ aumento da espessura das trabéculas indica deposição de novo material sobre elas, o que pode ser interpretado como neoformação óssea. 
Usando a nossa metodologia, a quantificação por micro-CT mostrou que os lados que continham SHED, apresentam uma maior porcentagem de trabéculas com tamanho de $0,186 \mathrm{~mm}$ de espessura, além de diminuição do volume dos poros do biomaterial, após 50 dias de cirurgia. $\mathrm{O}$ aumento na espessura sugere ocorrência de neoformação óssea, preenchendo os espaços vazios, conforme já evidenciado pela histologia. No lado contendo OOMDSC, o aumento da espessura das trabéculas foi detectado, todavia, não foi significativo. O que para nós não foi uma surpresa, pois como observado na histologia as ilhas ósseas deste grupo, ainda são pequenas e estão localizadas ou no centro dos poros, ou na periferia do biomaterial.

Dessa forma a maior quantidade de ilhas de neoformação óssea e o aumento da espessura das trabéculas, confirma mais uma vez que as SHED tem grande potencial osteogênico. Conforme já sugerido em trabalhos anteriores, SHED apresenta um potencial osteogênico equiparável ao das BMSC (SEO et al., 2008; YAMAZA et al., 2010). Verifica-se que as OOMDSC também apresentam um potencial osteogênico, apesar dele ser inferior aos da SHED, todavia, para aumenta-lo, talvez seja necessário modificar as OOMDSC com o uso de vetores de expressão para potencializar os resultados. Essa nossa hipótese é apoiada por diversos artigos na literatura, os quais estudaram as MDSC isoladas de diferentes regiões do corpo e verificaram um aumento significativo na neoformação óssea com a inserção de vetores virais contendo tanto BMP-2 ou BMP-4 (LEE; MUSGRAVE; et al., 2001; MESZAROS et al., 2012; SHEN et al., 2004; WRIGHT et al., 2002).

Frente aos resultados obtidos, julgamos importante avaliar qual a contribuição das células-tronco de origem humana no processo de neoformação óssea. O nosso trabalho mostrou que tanto as SHED e OOMDSC, estão localizadas no tecido conjuntivo e não se diferenciam diretamente em osteoblastos in vivo. Sendo assim, a menor neoformação óssea observada nos lados em que foram enxertadas OOMDSC não podem ser explicadas pela ausência destas células, visto que estas células ainda estão presentes no local do enxerto após 50 dias de cirurgia. Este resultado está em contradição com a maioria dos artigos da literatura, os quais tem mostrado que as células-tronco 
enxertadas, participam da regeneração óssea de defeitos críticos calvarianos (LAINO et al., 2006; MA et al., 2012; MESZAROS et al., 2012; PENG et al., 2002; SEO et al., 2008; WRIGHT et al., 2002; ZHENG et al., 2009). É possível que as diferenças encontradas sobre a origem da neoformação óssea, possam estar relacionadas à ação das células imunes do hospedeiro agindo contra as célulastronco humanas enxertadas. Em suporte a esta nossa hipótese, apontamos um experimento realizado por WRIGHT e colaboradores (2002), os quais enxertaram MDSC em camundongos imunocompetentes e após três semanas observaram pouquíssimas células vivas. Por outro lado, quando enxertaram em camundongos imunossuprimidos, eles observaram que a quantidade de células final, era a mesma. De fato, em 50 dias observamos pouquíssimas células humanas no tecido conjuntivo, além disto, utilizamos ratos Wistar imunocompetentes como modelo animal, enquanto que, nos artigos relacionados acima, são utilizados camundongos imunossuprimidos. Uma outra possibilidade, é que estas diferenças estejam relacionadas as diferentes espécies de animais, pois enquanto utilizamos ratos, a grande maioria dos estudos utilizaram camundongos. Contudo, é importante ressaltar que, mesmo que esteja havendo algum tipo de resposta imune, a presença das SHED e OOMDSC estão associadas a uma maior quantidade de neoformação óssea. De fato, estudos anteriores já demonstraram que a reação imune não impede a formação óssea (ENGSTRAND et al., 2000).

Tendo em vista que as ilhas ósseas neoformadas não contém células humanas aos 50 dias pós-cirúrgicos, levantamos duas hipóteses: a) as células humanas contribuem ativamente para neoformação óssea, contudo, com o remodelamento ósseo as células humanas teriam sido eliminadas; b) as células humanas participam do processo de neoformação óssea, induzindo as células do hospedeiro a se diferenciarem. Para testarmos tais hipóteses, avaliamos em 7, 15 e 30 dias após as cirurgias a presença das SHED, as quais parecem estar associadas a um processo de neoformação óssea maior. Como observado por histologia em tempos pós cirúrgicos mais precoces, as SHED foram encontradas no tecido conjuntivo e não há evidencia de neoformação óssea até 30 dias. Sendo assim, diante de tais observações, o que parece ser mais plausível é que estas células não estão se diferenciando em osteoblastos, uma vez que não 
haveria tempo suficiente entre 30 e 50 dias para a ocorrência de remodelamento do tecido osso.

A análise por micro-CT após 07, 15 e 30 dias nas regiões onde foram realizadas as cirurgias, sugere que modificações estejam ocorrendo na microarquitetura do biomaterial enxertado. As modificações na microarquitetura podem estar relacionadas à neoformação óssea ou à reabsorção mineral.

A análise das regiões em que foram enxertadas SHED sugere que após 30 dias, houve aumento de deposição mineral como demonstrado através do aumento da espessura das trabéculas, preenchimento dos canais de comunicação entre os poros do biomaterial (Conn.D) e unificação das estruturas que delimitam esses poros (Tb.N). Apesar de não identificarmos ilhas ósseas nos cortes histológicos corados com H.E até o 30 dia após a cirurgia, é possível que esta deposição mineral seja o início da mineralização da matriz extracelular, a qual avaliaremos pela coloração de Von Kossa em experimentos futuros.

Já no grupo controle, a diminuição do volume da amostra (BV/TV) é a única característica da microarquitetura que sofre modificação após 30 dias de cirurgia. Por não haver neoformação óssea detectável pela histologia e por micro-CT nestes períodos, acreditamos que essa redução do volume total seja uma consequência da ação dos osteoclastos, as células responsáveis pela reabsorção óssea, os quais encontra-se significativamente em maior número aos 15 dias, tanto em relação aos períodos anteriores quanto os períodos posteriores analisados. De fato outros estudos já demonstraram que a atividade dos osteoclastos são responsáveis pela reabsorção dos biomateriais de HA/ $\beta$-TCP e no remodelamento do osso neoformado no interior de seus poros (ROOHANIESFAHANI et al., 2012; TEITELBAUM, 2000). Além disso, há a possibilidade de que as SHED adicionadas ao biomaterial tenham inibido a reabsorção, uma vez que foi observado um aumento não significativo do número de osteoclastos aos 15 dias neste grupo. Outros estudos já correlacionaram a interação dos osteoclastos com as células-tronco, nestes trabalhos, foram demonstrados que as células-tronco inibem a formação dos osteoclastos (OSHITA et al., 2011; YAMAZA et al., 2010). 
Em resumo o nosso estudo, por diversas abordagens, sugere que as células-tronco estão associadas à mudanças da microarquitetura do biomaterial enxertado. Estes achados sugerem que as células-tronco humanas possam estar modulando o envolvimento dos osteoclastos, entretanto, elas não fazem parte da neoformação óssea, como observado em 50 dias. Assim sendo, é possível que as células tronco enxertadas no biomaterial secretem fatores de indução osteogênica. Esta hipótese também foi levantada por MIURA e colaboradores (2003), ao observarem que as SHED humanas não se diferenciavam diretamente em osteoblastos, e que provavelmente, induziam a neoformação óssea recrutando as células osteogênicas do hospedeiro.

Vale ressaltar que de acordo com o nosso conhecimento, estes resultados obtidos a partir dos experimentos de microtomografia computadorizada in vivo podem ser os primeiros obtidos na américa latina. E o estabelecimento da metodologia para obtenção destes dados, contribuem para futuros experimentos que possam fazer uso desta técnica. 


\section{Conclusão}

Em resumo, as OOMDSC se diferenciam em osteoblastos mais lentamente, contudo, são tão capazes de se diferenciarem em osteoblastos maduros in vitro quanto às SHED. Entretanto, in vivo esta equivalência não é mais observada; SHED induz mais neoformação óssea do que as OOMDSC.

Além disto, as células que compõem a neoformação óssea observada in vivo, não são de origem humana. As células humanas estão localizadas no tecido conjuntivo que preenche os poros do biomaterial em todos os períodos avaliados. Contudo, as células humanas enxertadas parecem estar envolvidas nas alterações da microarquitetura do biomaterial, tanto promovendo a neoformação óssea quanto modulando o envolvimento dos osteoclastos.

Além de tudo, o método de avaliação da neoformação óssea proposto por nós, corrobora os resultados obtidos por histologia. 


\section{Resumo}

A regeneração óssea é um processo fisiológico que promove a neoformação de tecido ósseo saudável e funcional com características idênticas antes da lesão. Entretanto, frente a defeitos críticos, o osso é incapaz de se regenerar espontaneamente. Diante destas deficiências, a bioengenharia de tecidos ósseos (BTO) é uma opção promissora para a regeneração deste tipo de defeito. A maioria das abordagens de BTO utiliza as células-tronco mesenquimais da medula óssea (BMSC), porém, a coleta de BMSC dos pacientes é um processo bastante invasivo e doloroso. Por estas desvantagens, a busca por abordagens acessíveis e menos invasivas de novas fontes de células-tronco (CT) se tornou necessária. Neste contexto, as células-tronco de polpa de dentes decíduos (SHED) foram identificadas e sua aplicação na BTO, desde então, vem sendo amplamente estudada devido ao seu potencial osteogênico e por se tratar de uma fonte não invasiva. A obtenção de célulastronco do músculo orbicular do lábio (OOMDSC) também não causa dor adicional aos indivíduos, pois os fragmentos deste tecido são rotineiramente descartados durante as cirurgias de reconstrução do lábio.

No presente trabalho investigamos o potencial de diferenciação osteoblástico in vitro e in vivo das OOMDSC e comparamos com as SHED, além disto, associamos estas células a biomateriais de HA/ $\beta$-TCP e investigamos a sua contribuição na neoformação óssea in vivo.

O imunofenótipo de cada amostra de SHED e OOMDSC foi verificado para certificar a identidade de CT mesenquimais. Em seguida, as células em cultura foram submetidas à diferenciação osteoblástica in vitro. Em 9 e 14 dias de diferenciação as OOMDSC apresentaram menor atividade de fosfatase alcalina $(p<0,0001)$ e menor marcação de matriz extracelular mineralizada, comparado às SHED $(p<0,001)$, enquanto que em 21 dias estas diferenças não foram mais observadas. Quando associadas a biomateriais e implantadas em defeitos críticos calvariais bilaterais em ratos Wistar, tanto OOMDSC e SHED foram capazes de induzir neoformação óssea após 50 dias de cirurgia, conforme evidenciado pela análise morfológica e por micro-CT. Todavia, as células ósseas encontradas nos sítios da neoformação óssea não eram de origem humana.

A avaliação da neoformação óssea in vivo induzida por SHED assim como a sua distribuição no enxerto foi verificada também em 07, 15 e 30 dias pós-cirúrgicos. Nestes períodos não há evidência de neoformação óssea, entretanto, as SHED estão localizadas no tecido conjuntivo que se forma e preenche o enxerto. Além disto, os dados sugerem que estas células estão relacionadas à modificações na microarquitetura do biomaterial e ainda à modulação dos números dos osteoclastos, também verificada nestas amostras. 
Portanto, podemos concluir que as OOMDSC são tão capazes de se diferenciar em osteoblastos quanto às SHED in vitro, porém esta diferenciação é mais lenta. Os experimentos in vivo indicam que as SHED possuem maior capacidade de indução à neoformação óssea quando comparadas às OOMDSC e que, em nosso modelo, as CT humanas não se diferenciam em osteoblastos in vivo. De qualquer forma a adição das CT ao biomaterial favorece a neoformação óssea, variações de microarquitetura e modulação dos osteoclastos. $O$ fato de as ilhas ósseas não serem de origem humana indica que as células-tronco possam estar secretando fatores de indução à osteogênese, estimulando a neoformação óssea a partir das células do hospedeiro. 


\section{Abstract}

Bone regeneration is a physiological process, which promotes the growth of tissue at the site of injury, with the same characteristics of the original bone. However, when faced with critical defects the bone is unable to regenerate spontaneously. Bone tissue engineering (BTE) is a promising option for regenerating this type of defect. The majority of the approaches in BTE use Bone Marrow derived Mesenchymal Stem Cells (BMSC); however, the aspiration of bone marrow is a very invasive and painful procedure. Due to these disadvantages, the search for new, affordable and less invasive sources of stem cells (SC) has become necessary. In this context, stem cells from exfoliated deciduous teeth (SHED) have been identified and their application in BTE, since then, has been widely studied because they can be obtained non-invasively and due to their osteogenic potential. Stem cells from the orbicularis oris muscle (OOMDSC) are also obtained non-invasively and do not cause additional pain to individuals, because the fragments of this tissue are routinely discarded during lip reconstruction surgeries.

In the present work we investigated, in vitro and in vivo, the osteoblastic differentiation potential of OOMDSC and compared with SHED; furthermore, we associated these cells with HA/ $\beta$-TCP scaffolds and investigate its contribution in the bone formation in vivo.

The immunophenotype of each OOMDSC and SHED sample was verified to attest their mesenchymal stem cell identity. Then, cell cultures were submitted to osteoblastic differentiation in vitro. In 9 and 14 days of differentiation, OOMDSC exhibited lower alkaline phosphatase activity $(p<0.0001)$ and lower mineralized extracellular matrix staining compared to SHED ( $p<0.001)$, whereas at 21 days, these differences were no longer observed. When associated with scaffolds and implanted into bilateral critical-sized calvarial defects in Wistar rats, both OOMDSC and SHED were able to induce bone formation after 50 days of surgery, as evidenced by morphological analysis and micro-CT. However, bone cells found at sites of bone formation were not of human origin.

The evaluation of new bone formation in vivo induced by SHED as well as its distribution in the graft was performed at 07, 15 and 30 days after surgery. During these periods there was no evidence of new bone formation, however, SHED were located in the connective tissue that formed and filled the graft. Furthermore, our results suggest that these cells are related to changes in the microarchitecture of the scaffold and also to the modulation of the number of osteoclasts observed in these samples.

In summary, our results suggest that OOMDSC are as capable to differentiate into osteoblasts as SHED in vitro, but this differentiation is slower. In vivo experiments indicate that SHED has a greater ability to induce bone 
formation when compared with OOMDSC, and that in our model, the human stem cells do not differentiate into osteoblasts in vivo. Nonetheless, the addition of SC to the scaffolds promotes bone formation, as well as variations in microarchitecture and modulation of osteoclasts. The fact that the bone islands are not of human origin indicates that the stem cells may be secreting osteogenesis-inducing factors, stimulating the host's cells to regenerate the defects. 


\section{Referências Bibliográficas}

ABUKAWA, $\mathrm{H}$. et al. The engineering of craniofacial tissues in the laboratory: a review of biomaterials for scaffolds and implant coatings. Dental clinics of North America, v. 50, n. 2, p. 205-16, viii, abr. 2006.

ALVAREZ-BARRETO, J. F. et al. Flow perfusion improves seeding of tissue engineering scaffolds with different architectures.Annals of biomedical engineering, mar. 2007.

BAR-SHAVIT, Z. Taking a toll on the bones: regulation of bone metabolism by innate immune regulators. Autoimmunity, v. 41, n. 3, p. 195-203, abr. 2008.

BAYERLEIN, T. et al. Evaluation of bone availability in the cleft area following secondary osteoplasty. Journal of cranio-maxillo-facial surgery: official publication of the European Association for Cranio-Maxillo-Facial Surgery, v. 34 Suppl 2, p. 57-61, set. 2006.

BONFIELD, T. L. et al. Defining human mesenchymal stem cell efficacy in vivo. Journal of inflammation (London, England), v. 7, n. 1, p. 51, jan. 2010.

BORRELLI, J. et al. Physiological challenges of bone repair. Journal of orthopaedic trauma, v. 26, n. 12, p. 708-11, dez. 2012.

BOUXSEIN, M. L. et al. Guidelines for assessment of bone microstructure in rodents using micro-computed tomography. Journal of bone and mineral research : the official journal of the American Society for Bone and Mineral Research, v. 25, n. 7, p. 1468-86, jul. 2010.

BUEHR, M. et al. Capture of authentic embryonic stem cells from rat blastocysts. Cell, $v$. 135, n. 7, p. 1287-98, 26 dez. 2008.

BUENO, D. F. et al. New source of muscle-derived stem cells with potential for alveolar bone reconstruction in cleft lip and/or palate patients. Tissue engineering. Part A, v. 15, n. 2, p. 427-35, fev. 2009.

BURG, K. J. et al. Comparative study of seeding methods for three-dimensional polymeric scaffolds. Journal of biomedical materials research, v. 51, n. 4, p. 642-9, 15 set. 2000.

CAPLAN, A. I. Mesenchymal stem cells. Journal of orthopaedic research : official publication of the Orthopaedic Research Society, v. 9, n. 5, p. 641-50, set. 1991.

CAPLAN, A. I. New era of cell-based orthopedic therapies. Tissue engineering. Part B, Reviews, v. 15, n. 2, p. 195-200, jun. 2009.

CHAPEKAR, M. S. Tissue engineering: challenges and opportunities. Journal of biomedical materials research, v. 53, n. 6, p. 617-20, jan. 2000.

CHEN, K. et al. Osteochondral interface generation by rabbit bone marrow stromal cells and osteoblasts coculture. Tissue engineering. Part A, v. 18, n. 17-18, p. 1902-11, set. 2012. 
CHOUDHERY, M. S. et al. Bone marrow derived mesenchymal stem cells from aged mice have reduced wound healing, angiogenesis, proliferation and anti-apoptosis capabilities. Cell biology international, v. 36, n. 8, p. 747-53, 1 ago. 2012.

COOPER, G. M. et al. Testing the critical size in calvarial bone defects: revisiting the concept of a critical-size defect. Plastic and reconstructive surgery, v. 125, n. 6, p. 1685-92, jun. 2010.

CORSI, K. A. et al. Regenerative medicine in orthopaedic surgery. Journal of orthopaedic research : official publication of the Orthopaedic Research Society, v. 25, n. 10, p. 1261-8, out. 2007.

DACULSI, G. et al. Current state of the art of biphasic calcium phosphate bioceramics. Journal of materials science. Materials in medicine, v. 14, n. 3, p. 195-200, mar. 2003.

DE BARI, C. et al. Multipotent mesenchymal stem cells from adult human synovial membrane. Arthritis and rheumatism, v. 44, n. 8, p. 1928-42, ago. 2001.

DE MENDONÇA COSTA, A. et al. Reconstruction of large cranial defects in nonimmunosuppressed experimental design with human dental pulp stem cells. The Journal of craniofacial surgery, v. 19, n. 1, p. 204-10, jan. 2008.

DIMITRIOU, R. et al. Bone regeneration: current concepts and future directions. BMC medicine, v. 9, p. 66, jan. 2011.

DOMINICl, M. et al. Minimal criteria for defining multipotent mesenchymal stromal cells. The International Society for Cellular Therapy position statement. Cytotherapy, v. 8, n. 4, p. 3157, jan. 2006.

EBERLI, D.; ATALA, A.; YOO, J. J. One and four layer acellular bladder matrix for fascial tissue reconstruction. Journal of materials science. Materials in medicine, v. 22, n. 3, p. 741-51, mar. 2011.

EL-GHANNAM, A. Bone reconstruction: from bioceramics to tissue engineering. Expert review of medical devices, v. 2, n. 1, p. 87-101, jan. 2005.

ENGSTRAND, T. et al. Transient production of bone morphogenetic protein 2 by allogeneic transplanted transduced cells induces bone formation. Human gene therapy, v. 11, n. 1, p. 205-11, 1 jan. 2000.

EVANS, M. J.; KAUFMAN, M. H. Establishment in culture of pluripotential cells from mouse embryos. Nature, v. 292, n. 5819, p. 154-6, 9 jul. 1981.

FRIEDENSTEIN, A J.; PIATETZKY-SHAPIRO, I. I.; PETRAKOVA, K. V. Osteogenesis in transplants of bone marrow cells. Journal of embryology and experimental morphology, v. 16, n. 3, p. 381-90, dez. 1966.

$\mathrm{GAO}$, X. et al. BMP2 is superior to BMP4 for promoting human muscle derived-stem cell mediated bone regeneration in a critical size calvarial defect model. Cell transplantation, 1 nov. 2012. 
GIANNOUDIS, P. V; EINHORN, T. A.; MARSH, D. Fracture healing: the diamond concept. Injury, v. 38 Suppl 4, p. S3-6, set. 2007.

GLOTZBACH, J. P. et al. Regenerative medicine. Current problems in surgery, v. 48, n. 3, p. 148-212, mar. 2011.

GOMES, P. S.; FERNANDES, M. H. Rodent models in bone-related research: the relevance of calvarial defects in the assessment of bone regeneration strategies. Laboratory animals, $\mathrm{v}$. 45, n. 1, p. 14-24, jan. 2011.

GOSAIN, A. K. et al. Osteogenesis in cranial defects: reassessment of the concept of critical size and the expression of TGF-beta isoforms. Plastic and reconstructive surgery, v. 106, n. 2, p. 360-71; discussion 372, ago. 2000.

GREGORY, C. A et al. An Alizarin red-based assay of mineralization by adherent cells in culture: comparison with cetylpyridinium chloride extraction. Analytical biochemistry, v. 329, n. 1, p. 77-84, 1 jun. 2004.

GRONTHOS, S. et al. Postnatal human dental pulp stem cells (DPSCs) in vitro and in vivo. Proceedings of the National Academy of Sciences of the United States of America, v. 97, n. 25, p. 13625-30, 5 dez. 2000.

HARLEY, B. A C. et al. Microarchitecture of three-dimensional scaffolds influences cell migration behavior via junction interactions. Biophysical journal, v. 95, n. 8, p. 4013-24, out. 2008.

$\mathrm{HIBI}, \mathrm{H}$. et al. Alveolar cleft osteoplasty using tissue-engineered osteogenic material. International journal of oral and maxillofacial surgery, v. 35, n. 6, p. 551-5, jun. 2006.

HOLZAPFEL, B. M. et al. Can bone tissue engineering contribute to therapy concepts after resection of musculoskeletal sarcoma? Sarcoma, v. 2013, p. 153640, jan. 2013.

HORWITZ, E. M. Advancing regenerative medicine the translational way. Science translational medicine, v. 5, n. 177, p. 177fs9, 20 mar. 2013.

HSU, Y.-C.; FUCHS, E. A family business: stem cell progeny join the niche to regulate homeostasis. Nature reviews. Molecular cell biology, v. 13, n. 2, p. 103-14, fev. 2012.

$\mathrm{HU}, \mathrm{Z}$.-M. et al. Induction of bone matrix protein expression by native bone matrix proteins in $\mathrm{C} 2 \mathrm{C} 12$ culture. Biomedical and environmental sciences : BES, v. 22, n. 2, p. 164-9, abr. 2009.

HUTMACHER, D. W. Scaffolds in tissue engineering bone and cartilage. Biomaterials, v. 21, n. 24, p. 2529-43, dez. 2000.

IN 'T ANKER, P. S. et al. Mesenchymal stem cells in human second-trimester bone marrow, liver, lung, and spleen exhibit a similar immunophenotype but a heterogeneous multilineage differentiation potential. Haematologica, v. 88, n. 8, p. 845-52, ago. 2003. 
JACKSON, W. M. et al. Differentiation and regeneration potential of mesenchymal progenitor cells derived from traumatized muscle tissue. Journal of cellular and molecular medicine, v. 15, n. 11, p. 2377-88, nov. 2011.

JANKOWSKI, R. J.; DEASY, B. M.; HUARD, J. Muscle-derived stem cells. Gene therapy, v. 9, n. 10, p. 642-7, maio. 2002.

JAZEDJE, T. et al. Human fallopian tube mesenchymal stromal cells enhance bone regeneration in a xenotransplanted model. Stem cell reviews, v. 8, n. 2, p. 355-62, jun. 2012.

JIMI, E. et al. The current and future therapies of bone regeneration to repair bone defects. International journal of dentistry, v. 2012, p. 148261, jan. 2012.

KARAGEORGIOU, V.; KAPLAN, D. Porosity of 3D biomaterial scaffolds and osteogenesis. Biomaterials, v. 26, n. 27, p. 5474-91, set. 2005.

KERKIS, I.; CAPLAN, A. I. Stem cells in dental pulp of deciduous teeth. Tissue engineering. Part B, Reviews, v. 18, n. 2, p. 129-38, abr. 2012.

KIMELMAN, N. et al. Review: gene- and stem cell-based therapeutics for bone regeneration and repair. Tissue engineering, v. 13, n. 6, p. 1135-50, jun. 2007.

LAINO, G. et al. An approachable human adult stem cell source for hard-tissue engineering. Journal of cellular physiology, v. 206, n. 3, p. 693-701, mar. 2006.

LAJTHA, L. G. Stem cell concepts. Nouvelle revue française d'hématologie, v. 21, n. 1, p. 59-65, jan. 1979.

LANGER, R.; VACANTI, J. P. Tissue engineering. Science (New York, N.Y.), v. 260, n. 5110, p. 920-6, 14 maio. 1993.

LEE, J. Y.; MUSGRAVE, D. et al. Effect of bone morphogenetic protein-2-expressing muscle-derived cells on healing of critical-sized bone defects in mice. The Journal of bone and joint surgery. American volume, v. 83-A, n. 7, p. 1032-9, jul. 2001.

LEE, Y. M.; SEOL, Y. J. et al. Tissue-engineered growth of bone by marrow cell transplantation using porous calcium metaphosphate matrices. Journal of biomedical materials research, v. 54, n. 2, p. 216-23, fev. 2001.

MA, L. et al. Cryopreserved dental pulp tissues of exfoliated deciduous teeth is a feasible stem cell resource for regenerative medicine. PloS one, v. 7, n. 12, p. e51777, jan. 2012.

MANKANI, M. H. et al. In vivo bone formation by human bone marrow stromal cells: reconstruction of the mouse calvarium and mandible. Stem cells (Dayton, Ohio), v. 24, n. 9, p. 2140-9, set. 2006.

MAO, J. J. et al. Craniofacial tissue engineering by stem cells. Journal of dental research, v. 85, n. 11, p. 966-79, nov. 2006.

MARESCHI, K. et al. Isolation of human mesenchymal stem cells: bone marrow versus umbilical cord blood. Haematologica, v. 86, n. 10, p. 1099-100, out. 2001. 
MASTROGIACOMO, M.; DERUBEIS, A. R.; CANCEDDA, R. Bone and cartilage formation by skeletal muscle derived cells. Journal of cellular physiology, v. 204, n. 2, p. 594-603, ago. 2005.

MEINEL, L. et al. Bone tissue engineering using human mesenchymal stem cells: effects of scaffold material and medium flow. Annals of biomedical engineering, v. 32, n. 1, p. 112-22, jan. 2004.

MESZAROS, L. B. et al. Effect of host sex and sex hormones on muscle-derived stem cellmediated bone formation and defect healing. Tissue engineering. Part A, v. 18, n. 17-18, p. 1751-9, set. 2012.

MIURA, M. et al. SHED: stem cells from human exfoliated deciduous teeth. Proceedings of the National Academy of Sciences of the United States of America, v. 100, n. 10, p. 5807-12, 13 maio. 2003.

MUSGRAVE, D.; PRUCHNIC, R. Human skeletal muscle cells in ex vivo gene therapy to deliver bone morphogenetic protein-2. Journal of Bone \& ..., v. 84, n. 1, p. 120-7, jan. 2002.

NAKAHARA, $\mathrm{H}$. et al. In vivo osteochondrogenic potential of cultured cells derived from the periosteum. Clinical orthopaedics and related research, n. 259, p. 223-32, out. 1990.

NIEMEYER, P. et al. Transplantation of human mesenchymal stem cells in a nonautogenous setting for bone regeneration in a rabbit critical-size defect model. Acta biomaterialia, v. 6, n. 3, p. 900-8, mar. 2010.

NOURBAKHSH, N. et al. Induced in vitro differentiation of neural-like cells from human exfoliated deciduous teeth-derived stem cells. The International journal of developmental biology, v. 55, n. 2, p. 189-95, jan. 2011.

OSHITA, K. et al. Human mesenchymal stem cells inhibit osteoclastogenesis through osteoprotegerin production. Arthritis \& Rheumatism, v. 63, n. 6, p. 1658-1667, jun. 2011.

PAGNI, G. et al. Bone repair cells for craniofacial regeneration.Advanced drug delivery reviews, set. 2012.

PENG, $H$. et al. Synergistic enhancement of bone formation and healing by stem cellexpressed VEGF and bone morphogenetic protein-4. Journal of Clinical Investigation, v. 110, n. 6, p. 751-759, 15 set. 2002.

PINTO, J. G. S. Enxerto autógeno $x$ biomateriais no tratamento de fraturas e deformidades faciais-uma revisão de conceitos atuais. Revista da Faculdade ..., 2010.

PITTENGER, M. F. et al. Multilineage potential of adult human mesenchymal stem cells. Science (New York, N.Y.), v. 284, n. 5411, p. 143-7, 2 abr. 1999.

PLACHOKOVA, A. S. et al. Early effect of platelet-rich plasma on bone healing in combination with an osteoconductive material in rat cranial defects.Clinical oral implants research, abr. 2007. 
POTTER, J. K.; ELLIS, E. Biomaterials for reconstruction of the internal orbit. Journal of oral and maxillofacial surgery : official journal of the American Association of Oral and Maxillofacial Surgeons, v. 62, n. 10, p. 1280-97, out. 2004.

RAUH, J. et al. Bioreactor systems for bone tissue engineering. Tissue engineering. Part B, Reviews, v. 17, n. 4, p. 263-80, ago. 2011.

RODRÍGUEZ-LOZANO, F. J. et al. Tissue engineering with dental pulp stem cells: isolation, characterization, and osteogenic differentiation. The Journal of craniofacial surgery, v. 23, n. 6 , p. e571-5, nov. 2012.

ROOHANI-ESFAHANI, S. I. et al. Repairing a critical-sized bone defect with highly porous modified and unmodified baghdadite scaffolds. Acta biomaterialia, v. 8, n. 11, p. 4162-72, nov. 2012.

ROOSA, S. M. M. et al. The pore size of polycaprolactone scaffolds has limited influence on bone regeneration in an in vivo model. Journal of biomedical materials research. Part $A, v$. 92, n. 1, p. 359-68, jan. 2010.

ROSS, M. H. et al. Histologia: Texto e Atlas: em Correlação Com Biologia Celular e Molecular. Guanabara Koogan, 6. ed, Rio de Janeiro, 2012, 1008p.

ROUWKEMA, J.; RIVRON, N. C.; VAN BLITTERSWIJK, C. A. Vascularization in tissue engineering. Trends in biotechnology, v. 26, n. 8, p. 434-41, ago. 2008.

RUBIO, D. et al. Spontaneous human adult stem cell transformation. Cancer research, v. 65, n. 8, p. 3035-9, 15 abr. 2005.

SCHMITZ, J. P.; HOLLINGER, J. O. The critical size defect as an experimental model for craniomandibulofacial nonunions. Clinical orthopaedics and related research, n. 205, p. 299308, abr. 1986.

SECCO, M. et al. Gene expression profile of mesenchymal stem cells from paired umbilical cord units: cord is different from blood. Stem cell reviews, v. 5, n. 4, p. 387-401, dez. 2009.

SEO, B. M. et al. SHED repair critical-size calvarial defects in mice. Oral diseases, v. 14, n. 5, p. 428-34, jul. 2008.

SEONG, J. M. et al. Stem cells in bone tissue engineering. Biomedical materials (Bristol, England), v. 5, n. 6, p. 062001, dez. 2010.

SHAPIRO, F. Bone development and its relation to fracture repair. The role of mesenchymal osteoblasts and surface osteoblasts. European cells \& materials, v. 15, p. 53-76, jan. 2008.

SHEN, H.-C. et al. Ex vivo gene therapy-induced endochondral bone formation: comparison of muscle-derived stem cells and different subpopulations of primary musclederived cells. Bone, v. 34, n. 6, p. 982-92, jun. 2004. 
SITTINGER, M.; HUTMACHER, D. W.; RISBUD, M. V. Current strategies for cell delivery in cartilage and bone regeneration. Current opinion in biotechnology, v. 15, n. 5, p. 411-8, out. 2004.

SONOYAMA, W. et al. Characterization of the apical papilla and its residing stem cells from human immature permanent teeth: a pilot study. Journal of endodontics, v. 34, n. 2, p. 166-71, fev. 2008.

STARK, G. B. et al. Biological wound tissue glue systems in wound healing. Langenbecks Archiv für Chirurgie. Supplement. Kongressband. Deutsche Gesellschaft für Chirurgie. Kongress, v. 115, p. 683-8, jan. 1998.

SUN, J.-S.; WU, S. Y.-H.; LIN, F.-H. The role of muscle-derived stem cells in bone tissue engineering. Biomaterials, v. 26, n. 18, p. 3953-60, jun. 2005.

SWIJNENBURG, R.-J. et al. Embryonic stem cell immunogenicity increases upon differentiation after transplantation into ischemic myocardium. Circulation, v. 112, n. 9 Suppl, p. I166-72, 30 ago. 2005.

SZPALSKI, C. et al. Bone tissue engineering: current strategies and techniques--part I: Scaffolds. Tissue engineering. Part B, Reviews, v. 18, n. 4, p. 246-57, ago. 2012.

TAMAKI, Y. et al. In vitro analysis of mesenchymal stem cells derived from human teeth and bone marrow. Odontology / the Society of the Nippon Dental University, 7 jul. 2012.

TEITELBAUM, S. L. Bone Resorption by Osteoclasts. Science, v. 289, n. 5484, p. 15041508, 1 set. 2000.

TETI, A. Bone development: overview of bone cells and signaling. Current osteoporosis reports, v. 9, n. 4, p. 264-73, dez. 2011.

THOMSON, J. A. et al. Embryonic stem cell lines derived from human blastocysts. Science (New York, N.Y.), v. 282, n. 5391, p. 1145-7, 6 nov. 1998.

TOMA, J. G. et al. Isolation of multipotent adult stem cells from the dermis of mammalian skin. Nature cell biology, v. 3, n. 9, p. 778-84, set. 2001.

TORTORA, G. J. et al. Princípios de Anatomia e Fisiologia. Guanabara, 12. ed, Rio de Janeiro, 2010, 1256p.

TUAN, R. S. Regenerative medicine in 2012: the coming of age of musculoskeletal tissue engineering. Nature reviews. Rheumatology, v. 9, n. 2, p. 74-6, fev. 2013.

VAN HOUT, W. M. M. T. et al. Reconstruction of the alveolar cleft: can growth factoraided tissue engineering replace autologous bone grafting? A literature review and systematic review of results obtained with bone morphogenetic protein-2. Clinical oral investigations, $v$. 15, n. 3, p. 297-303, jun. 2011.

WINKLER, J.; HESCHELER, J.; SACHINIDIS, A. Embryonic stem cells for basic research and potential clinical applications in cardiology. Biochimica et biophysica acta, v. 1740, n. 2, p. 2408, 30 maio. 2005. 
WRIGHT, V. et al. BMP4-expressing muscle-derived stem cells differentiate into osteogenic lineage and improve bone healing in immunocompetent mice. Molecular therapy: the journal of the American Society of Gene Therapy, v. 6, n. 2, p. 169-78, ago. 2002.

YAMAZA, T. et al. Immunomodulatory properties of stem cells from human exfoliated deciduous teeth. Stem cell research \& therapy, v. 1, n. 1, p. 5, jan. 2010.

$\mathrm{YE}, \mathrm{X}$. et al. Ectopic bone regeneration by human bone marrow mononucleated cells, undifferentiated and osteogenically differentiated bone marrow mesenchymal stem cells in beta-tricalcium phosphate scaffolds. Tissue engineering. Part C, Methods, v. 18, n. 7, p. 545-56, jul. 2012.

YIN, P. et al. Osteoblastic cell response on biphasic fluor-hydroxyapatite/strontiumsubstituted hydroxyapatite (FHA/SrHA) coatings. Journal of biomedical materials research. Part A, 27 mar. 2013.

ZHANG, Z.-Y. et al. The potential of human fetal mesenchymal stem cells for off-the-shelf bone tissue engineering application. Biomaterials, v. 33, n. 9, p. 2656-72, mar. 2012.

ZHENG, Y. et al. Stem cells from deciduous tooth repair mandibular defect in swine. Journal of dental research, v. 88, n. 3, p. 249-54, mar. 2009.

ZUK, P. A. et al. Multilineage cells from human adipose tissue: implications for cell-based therapies. Tissue engineering, v. 7, n. 2, p. 211-28, abr. 2001.

ZVAIFLER, N. J. et al. Mesenchymal precursor cells in the blood of normal individuals. Arthritis research, v. 2, n. 6, p. 477-88, jan. 2000. 


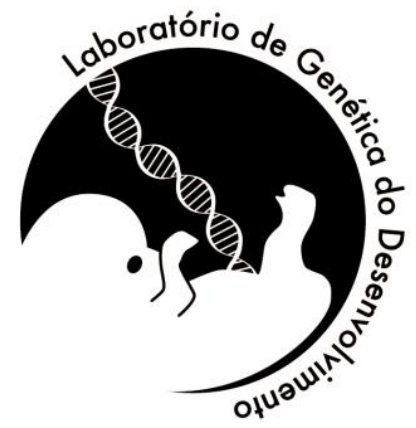

